\title{
Surface Physical Activity and Hydrophobicity of Designed Helical Peptide Amphiphiles Control Their Bioactivity and Cell Selectivity
}

DOI:

10.1021/acsami.6b08297

\section{Document Version}

Accepted author manuscript

Link to publication record in Manchester Research Explorer

Citation for published version (APA):

Chen, C., Yang, C., Chen, Y., Wang, F., Mu, Q., Zhang, J., Li, Z., Pan, F., Xu, H., \& Lu, J. R. (2016). Surface Physical Activity and Hydrophobicity of Designed Helical Peptide Amphiphiles Control Their Bioactivity and Cell Selectivity. ACS applied materials \& interfaces, 8(40), 26501-26510. https://doi.org/10.1021/acsami.6b08297

Published in:

ACS applied materials \& interfaces

\section{Citing this paper}

Please note that where the full-text provided on Manchester Research Explorer is the Author Accepted Manuscript or Proof version this may differ from the final Published version. If citing, it is advised that you check and use the publisher's definitive version.

\section{General rights}

Copyright and moral rights for the publications made accessible in the Research Explorer are retained by the authors and/or other copyright owners and it is a condition of accessing publications that users recognise and abide by the legal requirements associated with these rights.

\section{Takedown policy}

If you believe that this document breaches copyright please refer to the University of Manchester's Takedown Procedures [http://man.ac.uk/04Y6Bo] or contact uml.scholarlycommunications@manchester.ac.uk providing relevant details, so we can investigate your claim.

\section{OPEN ACCESS}




\section{Surface Physical Activity and Hydrophobicity of Designed Helical Peptide Amphiphiles Control Their Bioactivity and Cell Selectivity}

Cuixia Chen, ${ }^{\dagger}$ Cheng Yang, ${ }^{\dagger}$ Yucan Chen,${ }^{\dagger}$ Fang Wang, ${ }^{\dagger}$ Quanmeng Mu,${ }^{\dagger}$ Jing Zhang, ${ }^{\dagger}$

Zongyi Li, ${ }^{\ddagger}$ Fang Pan, ${ }^{\ddagger}$ Hai Xu, ${ }^{\dagger} * *$ and Jian Ren $\mathrm{Lu}^{\ddagger} * *$

${ }^{\dagger}$ Centre for Bioengineering and Biotechnology, China University of Petroleum (East China), 66

Changjiang West Road, Qingdao 266580, China

*Biological Physics Laboratory, School of Physics and Astronomy, University of Manchester,

Schuster Building, Manchester M13 9PL, UK 


\begin{abstract}
$\mathrm{G}(\mathrm{IIKK})_{3} \mathrm{I}-\mathrm{NH}_{2}(\mathrm{G} 3)$ has been recently shown to be highly effective at killing bacteria and inhibiting tumor cell growth while remaining benign to normal host mammalian cells. The aim of this work is to evaluate how residue substitutions of Ala (A), Val (V), Glu (E), and Lys (K) for the N-terminal Gly (G) or C-terminal Ile (I) of G3 affect the physiochemical properties and bioactivity of the variants. All substitutions caused the reduction of peptide hydrophobicity whilst N-terminal substitutions had less noticeable effect on the surface activity and helix-forming ability than C-terminal substitutions. $\mathrm{N}$-terminal variants held potent antitumor activity but exhibited much lower hemolytic activity; these actions were related to the maintenance of their moderate surface pressures (12 to $16 \mathrm{mN} / \mathrm{m}$ ) whilst their hydrophobicity was reduced. Thus, N-terminal substitutions enhanced the cell selectivity of the mutants relative to the control peptide G3. In contrast, C-terminal variants exhibited lower antitumor activity and further reduced hemolytic activity except for $\mathrm{G}(\mathrm{IIKK})_{3} \mathrm{~V}-\mathrm{NH}_{2}$. These features were also correlated well with their lower surface pressures $(\leq 10 \mathrm{mN} / \mathrm{m})$ and further decreased hydrophobicity. In spite of its very low helical content, the C-terminal variant $\mathrm{G}(\mathrm{IIKK})_{3} \mathrm{~V}-\mathrm{NH}_{2}$ still displayed potent antitumor activity whilst retaining high hemolytic activity as well, again correlating well with its relatively high surface pressure and hydrophobicity. These results together indicated that surface activity governs the antitumor activity of the peptides but relative hydrophobicity influences their hemolytic activity. In contrast, helicity appears to be poorly correlated to their bioactivity. This work has demonstrated that $\mathrm{N}$-terminal modifications provide a useful strategy to optimize the antitumor activity of helical anticancer peptides (ACPs) against its potential toxicity to mammalian host cells.
\end{abstract}

KEYWORDS: anticancer peptides; surface activity; hydrophobicity; helicity; antitumor activity; hemolytic activity; cell selectivity 


\section{INTRODUCTION}

With human cancer remaining a cause of high morbidity and mortality worldwide, novel, selective and more efficient drugs and treatments are urgently needed. Recent studies have reported the effective inhibition of cancer cell growth by amphipathic antimicrobial peptides (AMPs) via selectively disrupting cell membranes. ${ }^{1-4}$ AMPs that also show anticancer activities are called anticancer peptides (ACPs). Although ACPs exhibit many desirable properties such as broad spectrum activity, high structural stability and low probability of inducing resistance, ${ }^{3-5}$ their development as novel anticancer agents is hampered by their poor bioavailability, potential immunogenicity, cytotoxicity to host cells and high production costs. ${ }^{4,6}$ To circumvent these problems, researchers have tried to develop novel synthetic ACPs, e.g., by sequence modifications from naturally occurring template peptides, ${ }^{2,7}$ by D-amino acid substitution at the nonpolar surface, ${ }^{8,9}$ and by shortening peptide sequences to reduce cost. ${ }^{1,10,11}$

In the course of structural design for optimal ACPs, properties including sequence, length, net charge, secondary structure, amphipathicity and hydrophobicity must be carefully examined. ${ }^{1,4-5,12}$ The outer membrane surfaces of cancer cells are negatively charged and it is widely thought that cell death mediated by membrane-lytic ACPs starts with peptide binding to the outer membranes of tumor cells via electrostatic interactions between the positive charges of the peptides and the negatively charged groups on the outer membrane surfaces of cancer cells. ${ }^{2,5-6}$ Therefore, ACPs with net positive charges possess high affinity to cancer cells, leading to their rapid binding to cancer cell 
membranes. Upon membrane binding, hydrophobic interactions between peptides and membrane lipids would become dominant, and this process is strengthened by the conformational transition of ACPs (e.g., from disordered to helical transition) and the consequent formation of amphipathic structures, which would favor their insertion and self-association within the membrane core, as well as their translocation into the inner face of the lipid membrane, finally becoming internalized. ${ }^{2,}{ }^{4-5}$ The overall hydrophobicity of a helical ACP relies on not only the hydrophobicity of its constituent amino acids but also its helical propensity pertinent to peptide sequence. ${ }^{13}$ Increasing levels of hydrophobicity on the nonpolar face of a 26-residue $\alpha$-helical peptide (peptide P: Ac-KWKSFLKTFKSAKKTVLHTALKAISS-amide) enhanced peptide helicity and self-association ability, leading to higher anticancer activity but stronger hemolytic activity. ${ }^{14}$ To improve the cell specificity or therapeutic index of this peptide and its analogues, D-amino acids were introduced into the nonpolar face to modulate peptide hydrophobicity and helicity. ${ }^{15}$ Additionally, simple terminal modifications including N-terminal acetylation, C-terminal amidation, end-tagging and single amino acid substitutions have also been employed to alter the properties of AMPs and ACPs, with some of these peptide variants showing enhanced antibacterial and anticancer activity and cell selectivity. ${ }^{16-18}$ Furthermore, previous studies have also suggested that end capping and cyclization of hexameric peptide sequences of RRWQWR and RRWWRF or end-tagging of short peptides KNK10 (KNKGKKNGKH) and GKH17 (GKHKNKGKKNGKHNGWK) with hydrophobic Trp (W) or Phe (F) stretches could 
alter the susceptibility of AMPs to proteolytic degradation, thereby enhancing their stability in serum. ${ }^{19-21}$ Hence, terminal modifications could be a useful strategy for enhancing AMP and ACP's stability against proteolytic degradation. However, the influence of terminal modifications on the anticancer activity and cell selectivity of ACPs has not yet been understood well.

We have previously designed a serial of antitumor peptides, $\mathrm{G}(\mathrm{IIKK})_{\mathrm{n}} \mathrm{I}-\mathrm{NH}_{2}(\mathrm{n}=2-4)$, based on the common features of naturally occurring AMPs, i.e. amphiphilicity and cationicity. ${ }^{22-23}$ Among this serial of peptides, $\mathrm{G}(\mathrm{IIKK})_{3} \mathrm{I}-\mathrm{NH}_{2}$ was found to display high selectivity between tumor cells and normal mammalian host cells following the extensive examination of peptide length, net positive charges, helicity and hydrophobicity. Our recent study has indicated that whilst deleting its terminal amino acids had little impact on their antibacterial behavior, their antitumor activity declined sharply. ${ }^{25}$ To make a more systematic investigation of the effects of terminal modifications, we have synthesized 2 groups of peptides through single amino acid substitutions at the $\mathrm{N}$-terminus or C-terminus with hydrophobic amino acids (Ala or Val), positively charged amino acid (Lys), and negatively charged polar amino acid (Glu). The physicochemical properties of these peptides including their hydrophobicity, secondary structures and surface activity were assessed. Their bioactivity including antitumor activity and cytotoxicity to normal host cells was also examined. The results indicated that $\mathrm{N}$ - and C-terminal modifications could affect their physiochemical properties and bioactivity very differently. The surface activity of the peptides, quantified by surface pressure upon 
adsorption at the air/water interface, controlled their antitumor activity. However, the hydrophobicity of the peptides, quantified by retention times in reversed phase high performance liquid chromatograph (RP-HPLC), dictated their hemolytic activity. Maintenance of a relatively high surface pressure and attainment of decreased hydrophobicity from a single amino acid substitution, e.g., at the N-terminus of $\mathrm{G}(\mathrm{IIKK})_{3} \mathrm{I}-\mathrm{NH}_{2}$, can work as an efficient strategy to decrease cytotoxicity to mammalian host cells whilst retaining potent antitumor activity.

\section{EXPERIMETNAL SECTION}

Materials. Materials for peptide synthesis including Fmoc protected amino acids, Rink amide MBHA resin, solvents, and other chemical reagents were obtained from GL Biochem Ltd. (Shanghai, China). Piperidine, N,N-dimethylformamide (DMF) and dichloromethane $(\mathrm{DCM})$ were redistilled prior to use. 3-(4,5-dimethylthiazol-2-yl)-2,5-diphenyltetrazolium bromide (MTT), dipalmitoyl phosphatidyl choline (DPPC), dipalmitoyl phosphatidyl glycerol (DPPG), egg phosphatidyl choline (eggPC), egg phosphatidyl glycerol (eggPG), cholesterol, and calcein acetoxymethyl ester (calcein-AM) were purchased from Sigma Chemical Co. (St. Louis, Mo, USA). All materials were used as received unless otherwise specified. Water used in all experiments was processed with a Milli-Q Biocel ultrapure water system (Millipore), with a minimum resistivity of $18.2 \mathrm{M} \Omega \mathrm{cm}$.

Cells and Cell Culture. Tumor cells including HpeG2, HeLa, HL60 and Jurkat cells were purchased from Shanghai Institute for Biological Science (Shanghai, China). 
HpeG2 and HeLa were cultured at $37{ }^{\circ} \mathrm{C}$ under $5 \% \mathrm{CO}_{2}$ atmosphere in Iscove's modified Dulbecco's medium (IMDM, Gibco, Grand Island, NY, USA) containing 10\% heat-inactivated fetal bovine serum (FBS). HL60 and Jurkat cells were incubated in 1640 medium (Gibco, Grand Island, NY, USA) with $10 \%$ FBS at $37{ }^{\circ} \mathrm{C}$ under $5 \% \mathrm{CO}_{2}$ atmosphere. $\mathrm{HCa}$ cells (human chondrocytes from articular, \#4650) and the corresponding medium (\#4651) were purchased from ScienCell ${ }^{\mathrm{TM}}$ Research Laboratories (Carlsbad, CA, USA), and the cells were incubated in the medium at $37{ }^{\circ} \mathrm{C}$ under $5 \%$ $\mathrm{CO}_{2}$ atmosphere.

Peptides Synthesis and Purification. All peptides were synthesized on a CEM Liberty microwave synthesizer from their $\mathrm{C}$-termini to $\mathrm{N}$-termini based on the standard Fmoc solid-phase synthesis strategy. The use of Rink amide MBHA resin allowed their C-termini to be amidated. Cleavage of the peptides from the resin and final deprotection were performed concurrently with a mixture of trifluoroacetic acid (TFA), triisopropylsilane (TIS), and $\mathrm{H}_{2} \mathrm{O}$ at a ratio of 95:2.5:2.5. The crude products were precipitated and washed with cold ether for at least eight times, and then freezing-dried in a lyophilizer. Detailed synthesis and purification procedures have been described in our previous studies. ${ }^{23-25}$ The final products were subjected to RP-HPLC and matrix-assisted laser desorption/ionization time of flight mass spectrometry (MALDI-TOF-MS) analyses, indicting their correct sequences and high purities (more than 95\%). The fluffy peptide powders were dissolved in PBS or Milli-Q water at a concentration of $2 \mathrm{mM}$. Following filtration sterilization with a $0.22 \mu \mathrm{m}$ pore sterile filters, the peptide solutions were of 2 
$\mathrm{mM}$ stored at $-20{ }^{\circ} \mathrm{C}$ as the stock solutions.

Circular Dichroism (CD). To determine the secondary structures of peptides in different solutions, CD measurements were performed on a Bio-Logic MOS 450 spectrometer using a quartz cell of $1 \mathrm{~mm}$ path length. Spectra were recorded from 190 to $250 \mathrm{~nm}$ at room temperature at a scan speed of $50 \mathrm{~nm} / \mathrm{min}$. Samples were prepared by diluting the stock peptide solution $(2 \mathrm{mM})$ in aqueous solutions of DPPC and DPPG small unilamellar phospholipid vesicles (SUVs) to a final concentration of $0.5 \mathrm{mM}$. DPPC and DPPG SUVs were prepared by ultrasonic treatment as described previously. ${ }^{23}$ Background spectra were obtained in the absence of peptide. Baseline spectra for each solvent were obtained prior to the peptide spectra. The CD signals were presented as mean residual molar ellipticity $[\theta]\left(\mathrm{deg} \cdot \mathrm{cm}^{2} \cdot \mathrm{dmol}^{-1}\right)$ versus wavelength and each spectral profile was the average of at least six individual scans.

MTT Assays. Cell viability of HpeG2, HeLa, HL60, Jurkat and HCa cells treated with peptides was determined by the MTT assay. The cells were pre-seeded in a 96-well plate at concentration $1 \times 10^{5}$ cells $/ \mathrm{mL}$. After $24 \mathrm{~h}$ incubation, $100 \mu \mathrm{L}$ of peptide solutions (2-fold serial dilution) with different concentrations were added into the wells, followed by further incubation for $24 \mathrm{~h}$. Subsequently, $20 \mu \mathrm{L}$ of MTT $(5 \mathrm{mg} / \mathrm{mL})$ was added to each well. After incubation for $4 \mathrm{~h}$, the supernatant was discarded and the precipitated formazan was dissolved in $200 \mu \mathrm{L}$ of dimethyl sulfoxide (DMSO). The absorbance at 570 nm (A570) was measured by a microplate autoreader (Molecular Devices $\mathrm{M}^{2} \mathrm{e}$ ). Wells without cells were used as blanks and wells without peptides were taken as negative 
controls. Percentage of cell survival was expressed as a percent ratio of A570 of cells treated with peptide divided by that from control cells.

Hemolytic Activity. Fresh human red blood cells (hRBs) were collected by centrifugation (1000 g, $5 \mathrm{~min})$ of the blood from healthy volunteers. After washing at least three times with PBS buffer (pH 7.4), $100 \mu \mathrm{L}$ of hRBs suspended in PBS at 8\% (v/v) were mixed with $100 \mu \mathrm{L}$ of different 2 -fold diluted peptide solutions in a sterile 96 -well plate and incubated for $1 \mathrm{~h}$ at $37{ }^{\circ} \mathrm{C}$. After centrifugation at $1000 \mathrm{~g}$ for $10 \mathrm{~min}, 100 \mu \mathrm{L}$ aliquots of the supernatant were transferred into a new 96-well plate, and hemoglobin release was monitored by recording the absorbance at $540 \mathrm{~nm}$ (A540) with Molecular Devices $\mathrm{M}^{2}$ e. Erythrocytes in PBS and in $0.1 \%$ Triton $\mathrm{X}-100$ were employed as the negative and positive controls. All protocols in this section were carefully reviewed and approved by the Animal Experimental Ethical Committees of China University of Petroleum and Jilin University.

Surface Activity. Surface properties of peptides were assessed by measuring their surface pressures $(\pi, \mathrm{mN} / \mathrm{m})$ at the air/water interface using a multi-well plate supplied with the Micro trough X instrument (Kibron Inc., Helsinki, Finland). The multi-well plate was thoroughly cleaned by detergent solution, rinsed with hot water $\left(>60{ }^{\circ} \mathrm{C}\right)$, and then filled with $350 \mu \mathrm{L}$ of $10 \mathrm{mM}$ Tris buffer (with $150 \mathrm{mM} \mathrm{NaCl}, \mathrm{pH}$ 7.4). After injecting 5.3 $\mu \mathrm{L}$ of peptide solution $(0.2 \mathrm{mM})$ into the sub-phase via a microsyringe, surface pressures were monitored by using a Wilhelmy plate attaching to a Delta Pi microbalance (Kibron Inc., Helsinki, Finland). All experiments were conducted at $20 \pm 1^{\circ} \mathrm{C}$. 
Calcein Release Assay. HpeG2 or HCa cells $\left(1 \times 10^{5}\right.$ cells $\left./ \mathrm{mL}\right)$ were pre-seeded in a sterile 96-well plate for $24 \mathrm{~h}$ at $37{ }^{\circ} \mathrm{C}$ under $5 \% \mathrm{CO}_{2}$ atmosphere. The cells were then stained with calcein-AM $(1 \mu \mathrm{M})$ for 30 min at $37{ }^{\circ} \mathrm{C}$ in the dark, followed by washing with PBS to remove excessive dyes. After that $100 \mu \mathrm{L}$ of PBS and $100 \mu \mathrm{L}$ of peptide solution $(40 \mu \mathrm{M})$ were added into each well, resulting in a final peptide concentration of $20 \mu \mathrm{M}$. After incubation for the indicated time (10 $\mathrm{min}$ to $120 \mathrm{~min}$ ) at $37^{\circ} \mathrm{C}$, the calcein release to the supernatant was recorded by the microplate autoreader (Molecular Devices $\mathrm{M}^{2} \mathrm{e}$ ): excitation at $490 \mathrm{~nm}$ and emission at $515 \mathrm{~nm} .100 \%$ calcein release was obtained with addition of $0.1 \%$ Triton X-100 and 0\% release only with PBS.

\section{RESULTS AND DISCUSSION}

\subsection{Peptide Design and Their Physiochemical Properties}

$\mathrm{G}(\mathrm{IIKK})_{3} \mathrm{I}-\mathrm{NH}_{2}$ (G3) is a leading peptide identified from a list of designed AMPs that have been extensively studied in our previous work. It shows potent antibacterial and antitumor activity and low cytotoxicity to normal host mammalian cells. ${ }^{22-24}$ Furthermore, deleting the $\mathrm{N}$-terminal Gly residue and/or the C-terminal Ile residue in G3 can alter antitumor activity. ${ }^{24}$ As an effective strategy to stabilize helical structures in proteins, however, specific $\mathrm{N}$ - and C-capping motifs are widely exercised in many biological areas, ${ }^{25,}{ }^{26}$ resulting in different bioactivities. Interestingly, more than $70 \%$ of naturally occurring AMPs start with Gly residue in the N-terminus, which is thought to resist enzyme degradation. ${ }^{7}$ To better understand the effects of the terminal modifications of $\mathrm{G}(\mathrm{IIKK})_{3} \mathrm{I}-\mathrm{NH}_{2}$ on antitumor activity and to develop new variants with enhanced cell 
selectivity, we have designed two series of new peptides containing different capping groups at both termini, as shown in Table 1. Specifically, the N-terminal Gly or C-terminal Ile residue of $\mathrm{G}(\mathrm{IIKK})_{3} \mathrm{I}-\mathrm{NH}_{2}$ was replaced by 1) hydrophobic amino acids Ala and Val, both of which are more hydrophobic than Gly but less hydrophobic than Ile; 2) Glu, which contains a negative charge at its side chain, and 3) Lys, which adds one more positive charge at the $\mathrm{N}$-terminus or $\mathrm{C}$-terminus. The molecular masses of the synthesized peptides obtained from MALDI-TOF MS measurements were well consistent with their theoretical values, indicating that the products corresponded to the designed sequences (Table 1).

Table 1. Sequences and main features of the designed peptides

\begin{tabular}{|c|c|c|c|c|c|}
\hline \multirow[t]{2}{*}{ Peptides } & \multirow[t]{2}{*}{ Peptide sequences ${ }^{1}$} & \multirow{2}{*}{$\begin{array}{l}\text { Charges } \\
(\mathrm{pH} 7.4)\end{array}$} & \multicolumn{2}{|c|}{ Molecular masses } & \multirow{2}{*}{$\begin{array}{l}\text { Retention } \\
\text { times(min) }\end{array}$} \\
\hline & & & Calculated $^{2}$ & Measured $^{3}$ & \\
\hline A-I & $\mathrm{A}(\mathrm{IIKK})_{3} \mathrm{I}-\mathrm{NH}_{2}$ & +7 & 1649.3 & 1649.2 & 17.6 \\
\hline E-I & $\mathrm{E}(\mathrm{IIKK})_{3} \mathrm{I}-\mathrm{NH}_{2}$ & +6 & 1707.3 & 1706.9 & 17.5 \\
\hline K-I & $\mathrm{K}(\mathrm{IIKK})_{3} \mathrm{I}-\mathrm{NH}_{2}$ & +8 & 1706.4 & 1705.9 & 15.8 \\
\hline V-I & $\mathrm{V}(\mathrm{IIKK})_{3} \mathrm{I}-\mathrm{NH}_{2}$ & +7 & 1677.3 & 1676.8 & 16.9 \\
\hline G-I & $\mathrm{G}(\mathrm{IIKK})_{3} \mathrm{I}-\mathrm{NH}_{2}$ & +7 & 1635.2 & 1635.3 & 18.3 \\
\hline G-A & $\mathrm{G}(\mathrm{IIKK})_{3} \mathrm{~A}-\mathrm{NH}_{2}$ & +7 & 1593.1 & 1592.1 & 17.1 \\
\hline G-E & $\mathrm{G}(\mathrm{IIKK})_{3} \mathrm{E}-\mathrm{NH}_{2}$ & +6 & 1651.2 & 1650.7 & 16.7 \\
\hline G-K & $\mathrm{G}(\mathrm{IIKK})_{3} \mathrm{~K}-\mathrm{NH}_{2}$ & +8 & 1650.2 & 1649.8 & 15.8 \\
\hline G-V & $\mathrm{G}(\mathrm{IIKK})_{3} \mathrm{~V}-\mathrm{NH}_{2}$ & +7 & 1621.2 & 1621.2 & 18.0 \\
\hline
\end{tabular}

1) The peptide sequences are presented with the one letter amino acid code. ${ }^{2)}$ The theoretical molecular masses were calculated based on a peptide property calculator (http://www.pepcalc.com/). ${ }^{3)}$ The measured molecular masses were determined from MODAL-TOF MS measurements, corresponding to the $\mathrm{m} / \mathrm{z}$ values. 
Peptide Hydrophobicity. Peptide hydrophobicity was assessed by using RP-HPLC, which measures hydrophobic interactions between peptides and the nonpolar surface of the reversed stationary phase (typically C18-derivatized), expressed as retention time. Because of the broad similarity of the hydrophilic/hydrophobic interface provided by the chromatographic system to the cell membrane, the measured RP-HPLC retention times can be used as a useful implication of their hydrophobic interaction with the cell membrane. In addition to the hydrophobicity of each residue and peptide length, the retention time is also sensitive to the conformational state (e.g., amphipathicity and secondary structures) of peptides at the aqueous/C18 group interface. ${ }^{28}$ The formation of an amphipathic helical structure usually results in stronger retention on the hydrophobic column matrix, presumably through a preferred hydrophobic binding domain, and the RP-HPLC retention times of some helical peptides were thus found to correlate well with their helicities in CD measurements. . $^{13,27-29}$

It can be seen from Table 1 that the substitutions for either N-terminal Gly or C-terminal Ile decreased the retention times of the resulting peptides compared to the control peptide $\mathrm{G}(\mathrm{IIKK})_{3} \mathrm{I}-\mathrm{NH}_{2}$, indicative of reduction in their hydrophobicity. This is reasonable for the C-terminal variants because Ile is regarded as the most hydrophobic one among the five amino acids. ${ }^{30,} 31$ The hydrophobicity order of $\mathrm{G}(\mathrm{IIKK})_{3} \mathrm{I}-\mathrm{NH}_{2}>\mathrm{G}(\mathrm{IIKK})_{3} \mathrm{~V}-\mathrm{NH}_{2}>$ $\mathrm{G}(\mathrm{IIKK})_{3} \mathrm{~A}-\mathrm{NH}_{2}>\mathrm{G}(\mathrm{IIKK})_{3} \mathrm{E}-\mathrm{NH}_{2}>\mathrm{G}(\mathrm{IIKK})_{3} \mathrm{~K}-\mathrm{NH}_{2}$ is broadly consistent with that of individual amino acids $(\mathrm{I}>\mathrm{V}>\mathrm{A}>\mathrm{K} \sim \mathrm{E})$. Note that the intramolecular charge neutralization between $\mathrm{E}$ and $\mathrm{K}$ of $\mathrm{G}(\mathrm{IIKK})_{3} \mathrm{E}-\mathrm{NH}_{2}$ would increase its hydrophobicity. On 
the other hand, assuming that the peptides adopt $\alpha$-helical conformations at the hydrophilic/hydrophobic interface, C-terminal substitutions fall on the hydrophobic surface of the helical structures (Figure 1), thereby directly influencing the hydrophobic interaction of the resulting peptides with the hydrophobic C18 surface of the reversed-phase column. As a result, peptides with hydrophobic amino acids in the C-terminus possessed longer retention times and the values showed an increasing trend with the increasing hydrophobicity of the amino acids.

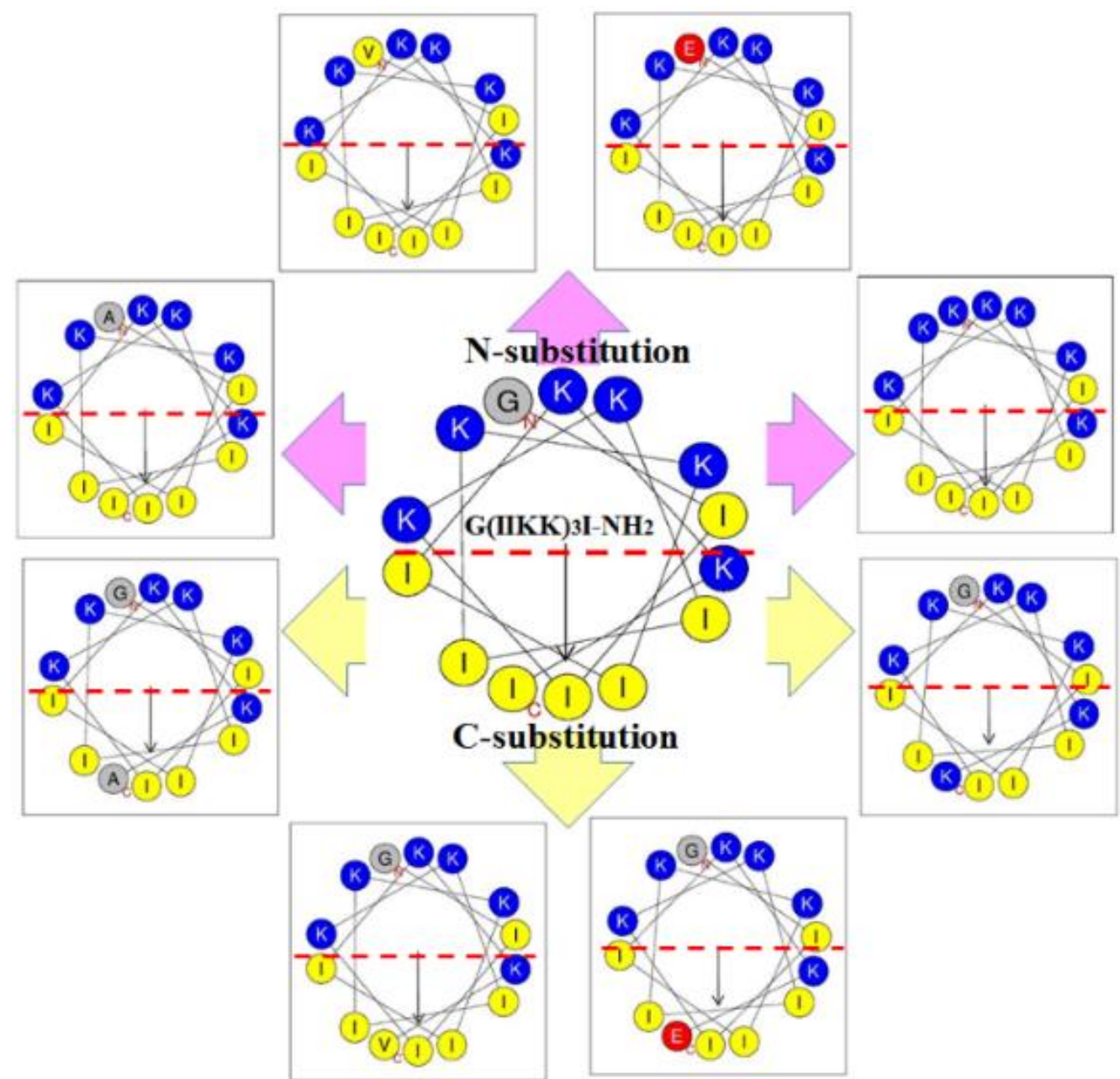

Figure 1. The Schiffer-Edmundson wheel projection of $\mathrm{G}(\mathrm{IIKK})_{3} \mathrm{I}-\mathrm{NH}_{2}$ (middle), its N-terminal variants (upper, pink arrows) and C-terminal variants (lower, yellow arrows). Yellow circles denote 
hydrophobic amino acid Ile, and blue circles represent hydrophilic amino acid Lys. Grey circles denote Gly or Ala. Red circles denote Glu. The wheels were drawn by using the online tool of the web site http://heliquest.ipmc.cnrs.fr/cgi-bin/ComutParams.py. The red point line separates the hydrophobic and hydrophilic sections.

However, the measured hydrophobicity of the N-terminal variants from RP-HPLC did not follow the hydrophobic order of individual amino acids (Table 1). For example, the hydrophobicity of Gly, Ala and Val is in the order of Val > Ala > Gly, ${ }^{30,}{ }^{31}$ but the hydrophobicity of the three corresponding peptides was opposite: $\mathrm{G}(\mathrm{IIKK})_{3} \mathrm{I}-\mathrm{NH}_{2}>$ $\mathrm{A}(\mathrm{IIKK})_{3} \mathrm{I}-\mathrm{NH}_{2}>\mathrm{V}(\mathrm{IIKK})_{3} \mathrm{I}-\mathrm{NH}_{2}$. Furthermore, the hydrophobicity of Glu is far lower than Val, but $\mathrm{E}(\mathrm{IIKK})_{3} \mathrm{I}-\mathrm{NH}_{2}$ showed a higher retention time than $\mathrm{V}(\mathrm{IIKK})_{3} \mathrm{I}-\mathrm{NH}_{2}$. The apparently contradicting phenomenon was also found in the different $\mathrm{N}$-terminal variants of the amphipathic helical peptide IVEEIEEVIGEGER studied by Spicer et al, in which the observed hydrophobicity of the N-terminal amino acid capped peptides from RP-HPLC was in the order: Gly > Glu Ala > Val > Lys and the N-terminal Gly capped one exhibited an usually high hydrophobicity value, ${ }^{33}$ broadly consistent with our observations. Assuming that the peptides take on $\alpha$-helical conformations at the hydrophilic/hydrophobic interface too, these $\mathrm{N}$-terminal substitutions fall on the hydrophilic surface of the helical structures (Figure 1), suggesting little direct influence on the hydrophobic interactions of the resulting peptides with the nonpolar surface of the stationary phase. However, such substitutions might influence the amphipathic feature, helical content and stability of the helical structures, which would in turn influence the 
hydrophobic interactions of the resulting peptides with the reversed phase column (see below).

Surface Property. Over 50\% of the active ACPs are physically surface active, suggesting that amphipathicity is a key driver of the membrane interactions for these peptides. ${ }^{4}$ As the air/water interface constitutes a useful model to investigate the interfacial affinity of peptides, ${ }^{33,34}$ we have compared the adsorption properties of the peptides at this interface. Figure 2 shows the surface pressure of each peptide with the final peptide concentration fixed at $3 \mu \mathrm{M}$. The surface pressure of all peptides increased immediately after injecting them into the sub-phase of Tris- $\mathrm{HCl}$ buffer and then tended to equilibration within $30 \mathrm{~min}$. Plots of surface pressure vs. time from the $\mathrm{N}$-terminal variants are shown in Figure 2A. The equilibrated surface pressures of $\mathrm{A}(\mathrm{IIKK})_{3} \mathrm{I}-\mathrm{NH}_{2}$, $\mathrm{E}(\mathrm{IIKK})_{3} \mathrm{I}-\mathrm{NH}_{2}$ and $\mathrm{V}(\mathrm{IIKK})_{3} \mathrm{I}-\mathrm{NH}_{2}$ were similar to that of the reference $\mathrm{G}(\mathrm{IIKK})_{3} \mathrm{I}-\mathrm{NH}_{2}$, being around $15 \mathrm{mN} / \mathrm{m}$. However, the final surface pressure of $\mathrm{K}(\mathrm{IIKK})_{3} \mathrm{I}-\mathrm{NH}_{2}$ was about $12 \mathrm{mN} / \mathrm{m}$, lower than those of the other peptides, which is reminiscent of its lowest hydrophobicity (Table 1) and helicity in this series (Figure 4a). In general, the higher the surface pressure, the more amphipathically balanced the molecule is. The equilibrated surface pressures of this serial of peptides fall in the middle of those already described for EB1 $(10 \mathrm{mN} / \mathrm{m}), \operatorname{MAP}(14 \mathrm{mN} / \mathrm{m})$, TP10 $(20 \mathrm{mN} / \mathrm{m})$ and $\mathrm{P} \alpha(25 \mathrm{mN} / \mathrm{m})$, which are typical cell-penetrating peptides and which adopt helical conformations in the presence of negatively charged phospholipids, being indicative of a clear amphipathic character. ${ }^{34,35}$

Interestingly, the equilibrated surface pressure values of the C-terminal variants 
changed greatly and the order was: $\mathrm{G}(\mathrm{IIKK})_{3} \mathrm{I}-\mathrm{NH}_{2}(15 \mathrm{mN} / \mathrm{m})>\mathrm{G}(\mathrm{IIKK})_{3} \mathrm{~V}-\mathrm{NH}_{2}(13$ $\mathrm{mN} / \mathrm{m})>\mathrm{G}(\mathrm{IIKK})_{3} \mathrm{~A}-\mathrm{NH}_{2}(10 \mathrm{mN} / \mathrm{m})>\mathrm{G}(\mathrm{IIKK})_{3} \mathrm{~K}-\mathrm{NH}_{2}(6 \mathrm{mN} / \mathrm{m})>\mathrm{G}(\mathrm{IIKK})_{3} \mathrm{E}-\mathrm{NH}_{2}(5$ $\mathrm{mN} / \mathrm{m}$ ) (Figure $2 \mathrm{~B})$, broadly consistent with their hydrophobic order $\left(\mathrm{G}(\mathrm{IIKK})_{3} \mathrm{I}-\mathrm{NH}_{2}>\right.$ $\left.\mathrm{G}(\mathrm{IIKK})_{3} \mathrm{~V}-\mathrm{NH}_{2}>\mathrm{G}(\mathrm{IIKK})_{3} \mathrm{~A}-\mathrm{NH}_{2}>\mathrm{G}(\mathrm{IIKK})_{3} \mathrm{E}-\mathrm{NH}_{2}>\mathrm{G}(\mathrm{IIKK})_{3} \mathrm{~K}-\mathrm{NH}_{2}\right)$. The surface pressure values for $\mathrm{G}(\mathrm{IIKK})_{3} \mathrm{E}-\mathrm{NH}_{2}(5 \mathrm{mN} / \mathrm{m})$ and $\mathrm{G}(\mathrm{IIKK})_{3} \mathrm{~K}-\mathrm{NH}_{2}(6 \mathrm{mN} / \mathrm{m})$ are similar to that observed form Pep-1 (4 mN/m) ${ }^{36}$ suggesting a weak amphipathic character associated with these peptides.

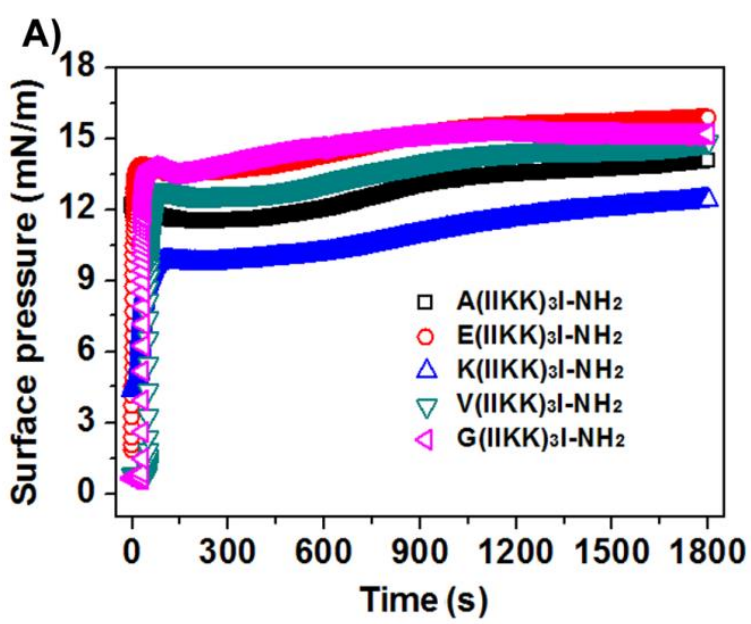

B)

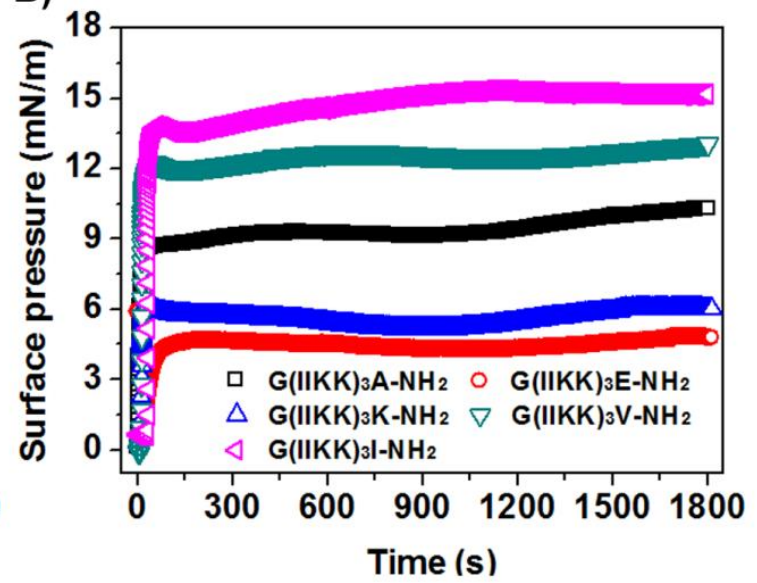

Figure 2. Surface pressures achieved from peptide adsorption to the air/water interface. A) N-terminal variants and B) C-terminal variants. The sub-phase was Tris- $\mathrm{HCl}$ with $150 \mathrm{mM} \mathrm{NaCl}(\mathrm{pH} 7.4)$. The final peptide concentration was fixed at $3 \mu \mathrm{M}$ and all experiments were performed at $20 \pm 1{ }^{\circ} \mathrm{C}$.

As shown in Figure 3, plots of surface pressure vs. retention time indicated a positive correlation between surface physical activity and hydrophobicity for the N-terminal variants $\left(r^{2}=0.44\right)$ and the $C$-terminal variants $\left(r^{2}=0.86\right)$ separately, i.e. larger retention times generally corresponding to higher surface pressures. However, such a correlation 
was quite different between the two groups of peptides. For the $\mathrm{N}$-terminal variants, the slope of the trend line was about 1.07 , and the increase of surface activity caused by the increased hydrophobicity was gentle. As a result, some deviations occurred over a narrower range of hydrophobicity, i.e., $\mathrm{A}(\mathrm{IIKK})_{3} \mathrm{I}-\mathrm{NH}_{2}$ showing slightly lower surface pressure than $\mathrm{E}(\mathrm{IIKK})_{3} \mathrm{I}-\mathrm{NH}_{2}$ and $\mathrm{V}(\mathrm{IIKK})_{3} \mathrm{I}-\mathrm{NH}_{2}$ in spite of having larger hydrophobicity.

In contrast, the slope was about 3.54 for the $\mathrm{C}$-terminal variants, suggesting that surface activity increased markedly with the increase of peptide hydrophobicity. When the peptide from the C-terminal variants had the same hydrophobicity as that from the $\mathrm{N}$-terminal variants, they exhibited different surface activities. For example, the surface pressure of $\mathrm{K}(\mathrm{IIKK})_{3} \mathrm{I}-\mathrm{NH}_{2}$ was 2-fold higher than that of $\mathrm{G}(\mathrm{IIKK})_{3} \mathrm{~K}-\mathrm{NH}_{2}$, even though they had the same retention time $(\sim 15.8 \mathrm{~min})$. These results suggest that $\mathrm{N}$-terminal modifications have marginal effect on the amphipathic changes, whereas C-terminal modifications especially with the charged amino acids greatly reduce peptide amphipathicity in the series. 

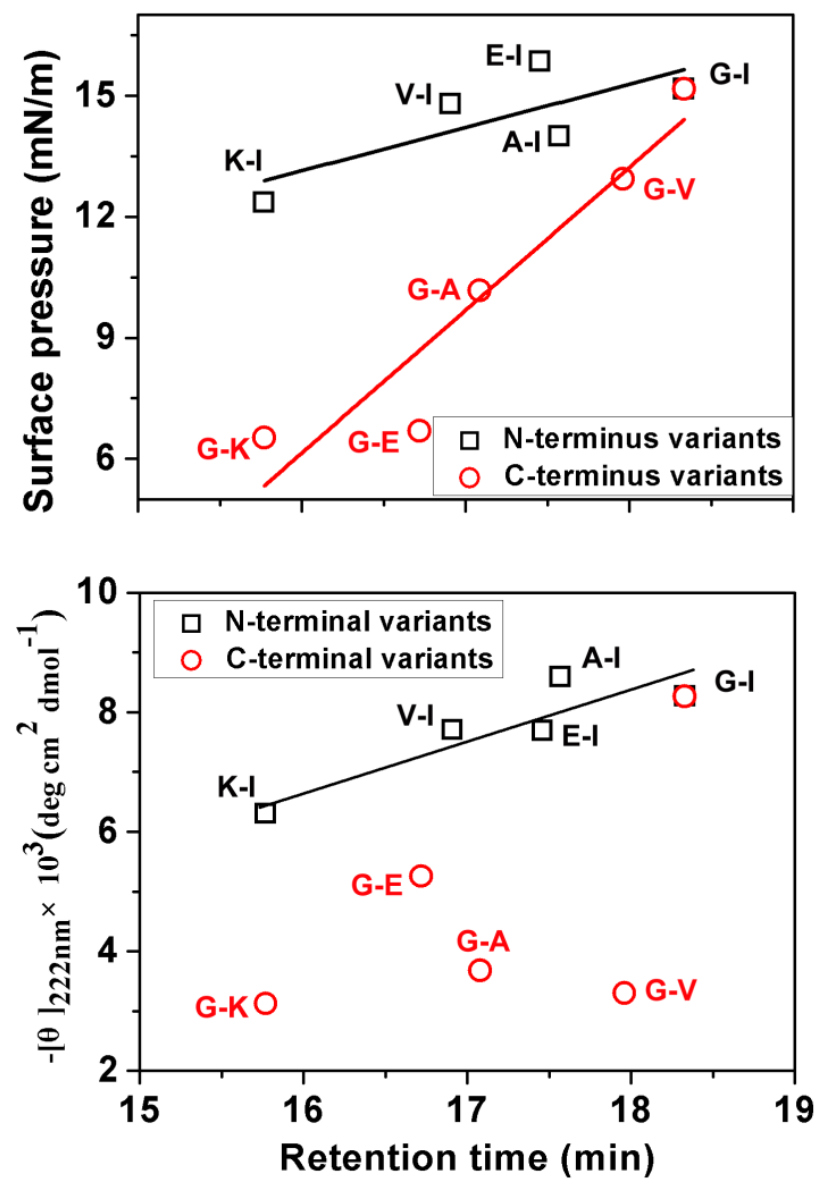

Figure 3. Correlation between A) the surface pressure values achieved from peptide adsorption to the air/water interface and the hydrophobicity (retention time from RP-HPLC) and B) the helicities at 222 $\mathrm{nm}$ of the peptides measured in DPPG SUVs and the hydrophobicity.

Helical Structure. CD was used to determine the secondary structures of the peptides. In water, these peptides adopted random coil conformation, due to the considerable intermolecular hydrogen bonding between peptide backbones and water molecules and also the strong intramolecular electrostatic repulsion between neighboring positively charged Lys side chains. Even in neutral DPPC SUVs, a hydrophobic environment mimicking normal cell membranes, the CD spectra of all peptides showed negative peaks 
in the region below $200 \mathrm{~nm}$ (Figures 4A and 4B), characteristic of random coil conformation. In the aqueous solutions of negatively charged DPPG SUVs that mimic bacterial and cell membranes, however, these peptides underwent a conformational transition, showing a positive CD peak near $193 \mathrm{~nm}$ and double negative CD peaks at 208 $\mathrm{nm}$ and $222 \mathrm{~nm}$ (Figures $4 \mathrm{a}$ and 4b), characteristic of $\alpha$-helical structures. Comparing the negative peaks at $222 \mathrm{~nm}$ of these peptides in DPPG SUVs, the correlation of helicity with retention time for the $\mathrm{N}$-terminal variants $\left(\mathrm{r}^{2}=0.72\right)$ is similar to that of surface pressure with retention time, i.e., helicity increased gently with increased hydrophobicity. $\mathrm{K}(\mathrm{IIKK})_{3} \mathrm{I}-\mathrm{NH}_{2}$ showed the lowest hydrophobicity, surface pressure and helical content in this group (Figure 3B). That the N-terminal modification with a positively charged amino acid (Lys) destabilized the helical conformation is most likely due to the increased repulsive interaction between charged side chains. ${ }^{26}$ This observation was similar to that of a smaller helical peptide $\mathrm{K}^{0}-\mathrm{W}^{6}-\mathrm{Hy}-\mathrm{al}^{18}$

Similar to the surface pressure, the peptide helicity for the C-terminal variants also showed a marked variation with hydrophobicity (Figure 3B). However, their correlation was very weak, the helicities of all the C-terminal variants being significantly reduced compared with that of the reference $\mathrm{G}(\mathrm{IIKK})_{3} \mathrm{I}-\mathrm{NH}_{2}$ (Figures $3 \mathrm{~B}$ and $4 \mathrm{~b}$ ). Although having clearly different hydrophobicities, $\mathrm{G}(\mathrm{IIKK})_{3} \mathrm{~K}-\mathrm{NH}_{2}, \mathrm{G}(\mathrm{IIKK})_{3} \mathrm{~A}-\mathrm{NH}_{2}$, and $\mathrm{G}(\mathrm{IIKK})_{3} \mathrm{~V}-\mathrm{NH}_{2}$ showed comparable helical contents. $\mathrm{G}(\mathrm{IIKK})_{3} \mathrm{E}-\mathrm{NH}_{2}$ exhibited a higher helical content than other three variants, presumably due to the introduction of the electrostatic attraction between the negatively charged carboxyl group and the positive 
pole of the $\alpha$-helix macrodipole. ${ }^{26}$ Although Chakrabartty et al. have indicated that C-terminal amino acids had a minor effect on the peptide helix stability relative to the $\mathrm{N}$-terminal ones, our study clearly demonstrated that it was the C-terminal substitutions that substantially altered its helicity as revealed by the CD measurements in negatively charged DPPG SUVs (Figures 3B and 4b), and the surface pressures as well (Figures $2 b$ and $3 \mathrm{~A})$. On the contrary, the N-terminal substitutions of $\mathrm{G}(\mathrm{IIKK})_{3} \mathrm{I}-\mathrm{NH}_{2}$ could only result in much milder changes in helicity and surface pressure (Figure 4a, Figure 3, and Figure 2a).
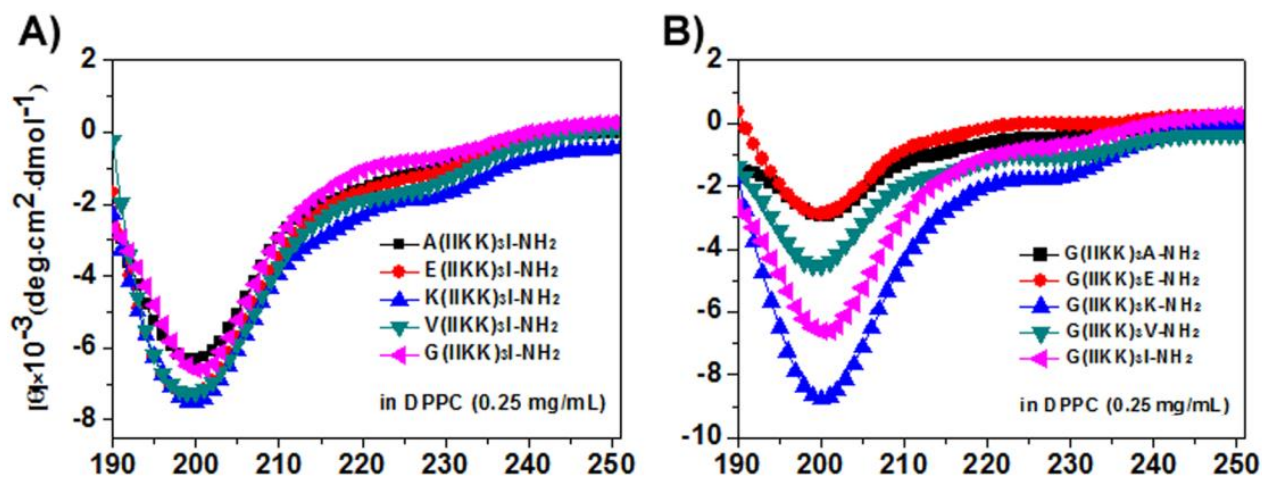

a)

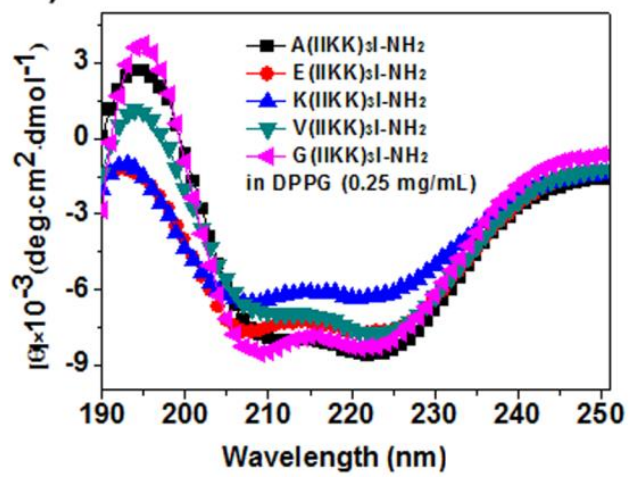

b)

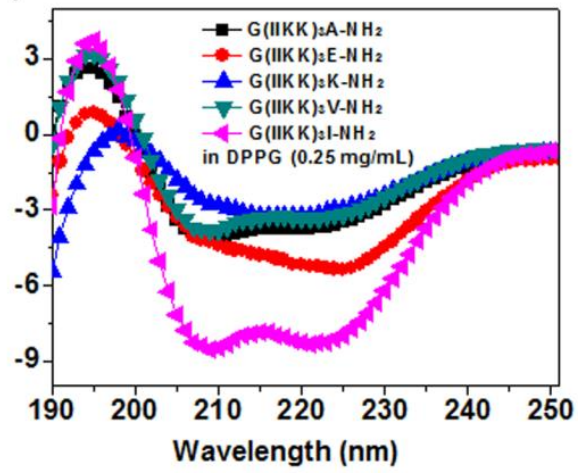

Figure 4. CD spectra of peptides in A,B) DPPC and a,b) DPPG SUVs. Peptide concentration was fixed at $0.5 \mathrm{mM}$ and the concentration of DPPC and DPPG was $0.25 \mathrm{mg} / \mathrm{mL}$.

\subsection{Bioactivities}


The activities of the peptides against solid tumor cells including HpeG2 and HeLa and leukemia cells including HL60 and Jurkat cells were examined using the MTT assay and the results are shown in Figure 5. Overall, all N-terminal peptide variants showed effective antitumor activities, with their $\mathrm{IC}_{50}$ (concentration causing $50 \%$ tumor cell growth inhibition) values mostly being in the range of 5-20 $\mu \mathrm{M}$, while the C-terminal variants were inferior except the reference $\mathrm{G}(\mathrm{IIKK})_{3} \mathrm{I}-\mathrm{NH}_{2}$ and the variant $\mathrm{G}(\mathrm{IIKK})_{3} \mathrm{~V}-\mathrm{NH}_{2}$, by the same assessment criteria. It is very interesting that $\mathrm{K}(\mathrm{IIKK})_{3} \mathrm{I}-\mathrm{NH}_{2}$ also displayed potent antitumor activities, with $\mathrm{IC}_{50}$ values of $\sim 5 \mu \mathrm{M}$ against HeLa and HL 60 cells, in spite of its lowest hydrophobicity, surface pressure, and helicity in this series. This is possibly related to the additional Lys residue that is located on the hydrophilic surface upon helix formation and thus favors the peptide to bind more efficiently onto the outer membrane leaflet of tumor cells via electrostatic interactions. This result suggests that the electrostatic interaction plays an essential role in enhancing antitumor activity. Although N-terminal Gly was widely considered to help stabilize peptides under serum conditions, ${ }^{7}$ its substitution from $\mathrm{G}(\mathrm{IIKK})_{3} \mathrm{I}-\mathrm{NH}_{2}$ in this study did not cause any measurable peptide degradation in serum (Figure S1).

In contrast, the antitumor activities of the C-terminal variants changed a lot (Figure 5 a-d). In addition to $\mathrm{G}(\mathrm{IIKK})_{3} \mathrm{~V}-\mathrm{NH}_{2}$, which had similar antitumor activities to the reference peptide $\mathrm{G}(\mathrm{IIKK})_{3} \mathrm{I}-\mathrm{NH}_{2}$ with their $\mathrm{IC}_{50}$ values of about $10 \mu \mathrm{M}$ against different tumor cells, the other three variants with Lys, Glu and Ala as C-termini only caused about $25 \%$ growth inhibition of different tumor cells at the concentration of $40 \mu \mathrm{M}$ (Figure 5 
a-d).

Generally, the peptides with higher antitumor activities showed slightly higher toxicity to normal mammalian $\mathrm{HCa}$ cells (Figures 6A and 6a). Relative to the reference peptide $\mathrm{G}(\mathrm{IIKK})_{3} \mathrm{I}-\mathrm{NH}_{2}$ that caused $\sim 50 \%$ erythrocyte hemolysis at $\sim 500 \mu \mathrm{M}$, the hemolytic activity of all the N-terminal variants was significantly decreased (Figure 6B). For example, $\mathrm{V}(\mathrm{IIKK})_{3} \mathrm{I}-\mathrm{NH}_{2}$ only caused $\sim 15 \%$ erythrocyte hemolysis at the same concentration. Note that $\mathrm{G}(\mathrm{IIKK})_{3} \mathrm{I}-\mathrm{NH}_{2}$ was milder to human primary cells (HCa cells) than to human blood cells while $\mathrm{K}(\mathrm{IIKK})_{3} \mathrm{I}-\mathrm{NH}_{2}$ was opposite (Figures $6 \mathrm{~A}$ and $6 \mathrm{~B}$ ). The underlying molecular explanation for this discrepancy remained to be identified in the future, but it might arise from the different membrane compositions of the two cell types. The hemolytic ability of the C-terminal variants was broadly consistent with their antitumor activities: $\mathrm{G}(\mathrm{IIKK})_{3} \mathrm{I}-\mathrm{NH}_{2}>\mathrm{G}(\mathrm{IIKK})_{3} \mathrm{~V}-\mathrm{NH}_{2}>\mathrm{G}(\mathrm{IIKK})_{3} \mathrm{~A}-\mathrm{NH}_{2}>$ $\mathrm{G}(\mathrm{IIKK})_{3} \mathrm{~K}-\mathrm{NH}_{2} \sim \mathrm{G}(\mathrm{IIKK})_{3} \mathrm{E}-\mathrm{NH}_{2}$ (Figure 6b). G(IIKK)$)_{3} \mathrm{E}-\mathrm{NH}_{2}$ and $\mathrm{G}(\mathrm{IIKK})_{3} \mathrm{~K}-\mathrm{NH}_{2}$ had little toxicity to $\mathrm{HCa}$ cells and did not cause any hemolysis at all, even at concentrations up to $500 \mu \mathrm{M}$ (Figures 6a and 6b). It has been reported that an uninterrupted sector of 5 hydrophobic residues of $\alpha$-helical AMPs was sufficient for their good antimicrobial activity. ${ }^{37,38}$ Here, all the peptides in this study contain at least 5 undisrupted Ile residues $\left(\mathrm{I}_{3}, \mathrm{I}_{6}, \mathrm{I}_{7}, \mathrm{I}_{10}\right.$, and $\left.\mathrm{I}_{11}\right)$ in the hydrophobic surface and furthermore, their terminal residues are located on the ends of helical wheels (Figure 1). Their bioactivities, in particular for the C-terminal variants, were found to vary over a wide range, indicating that the exact bioactivities of the peptides may be influenced by other 
factors such as their hydrophobicity, surface pressure, and helicity. The above physical measurements indicated that $\mathrm{N}$ - and $\mathrm{C}$-terminal modifications imposed marked impact on these factors, also in particular for the C-terminal variants, resulting in very different bioactivity. 

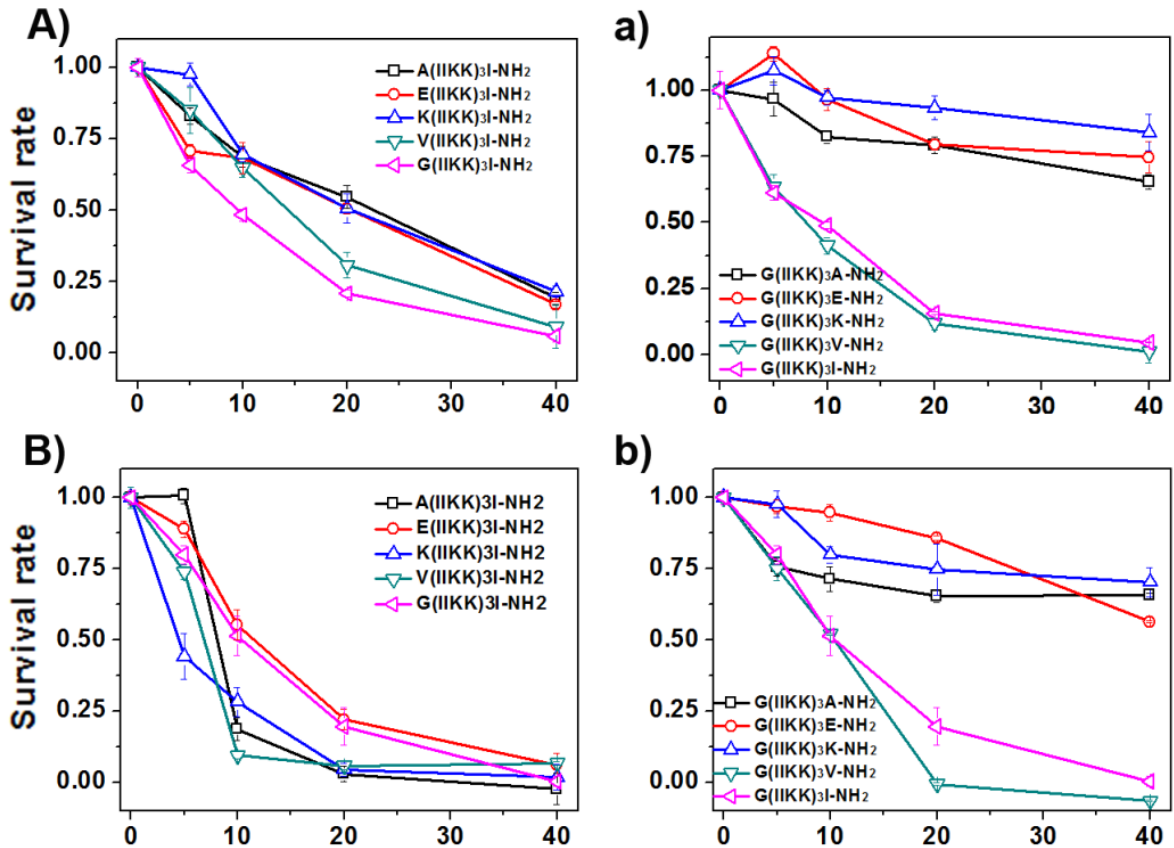

b)
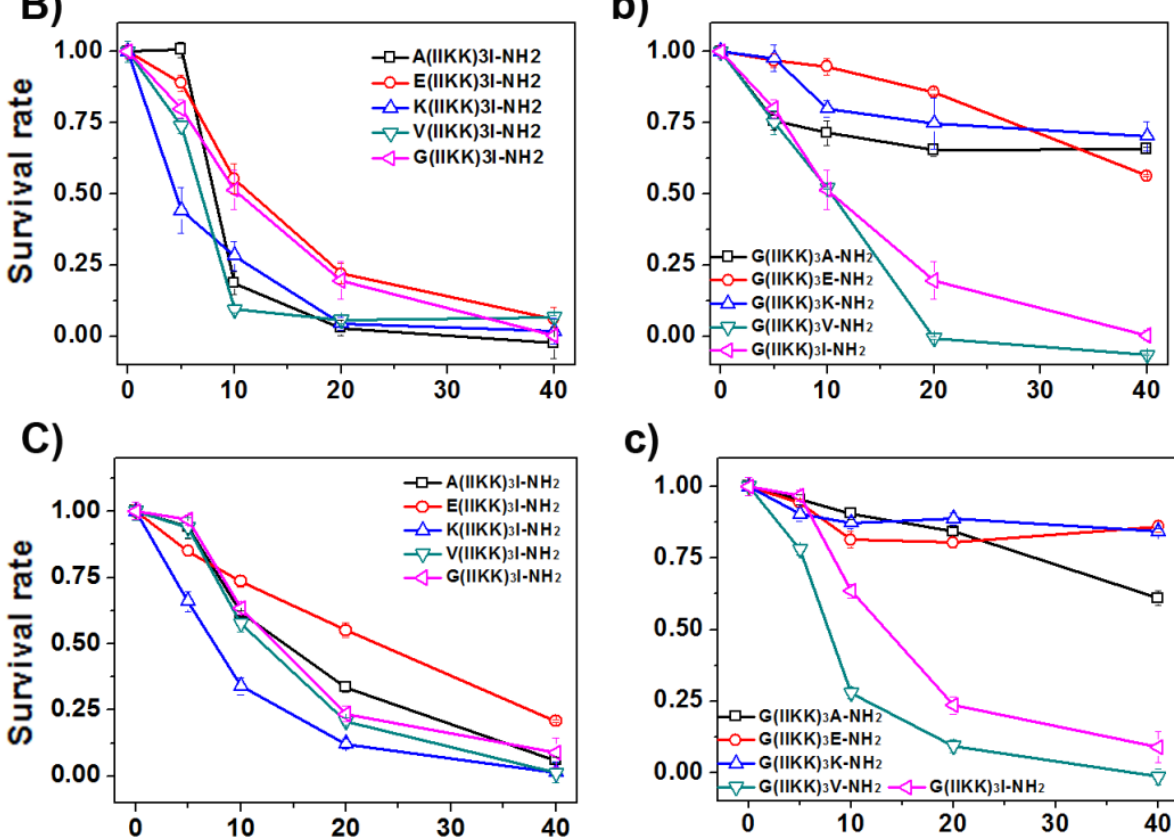

c)

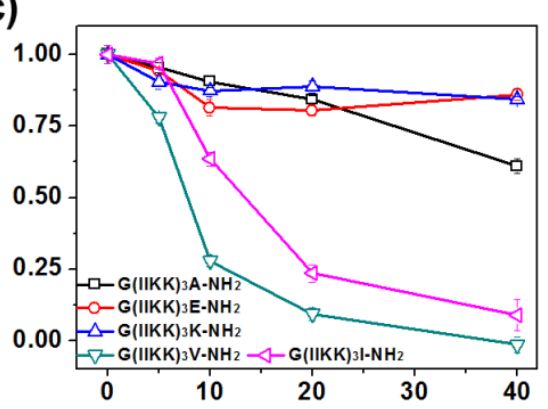

D)

d)
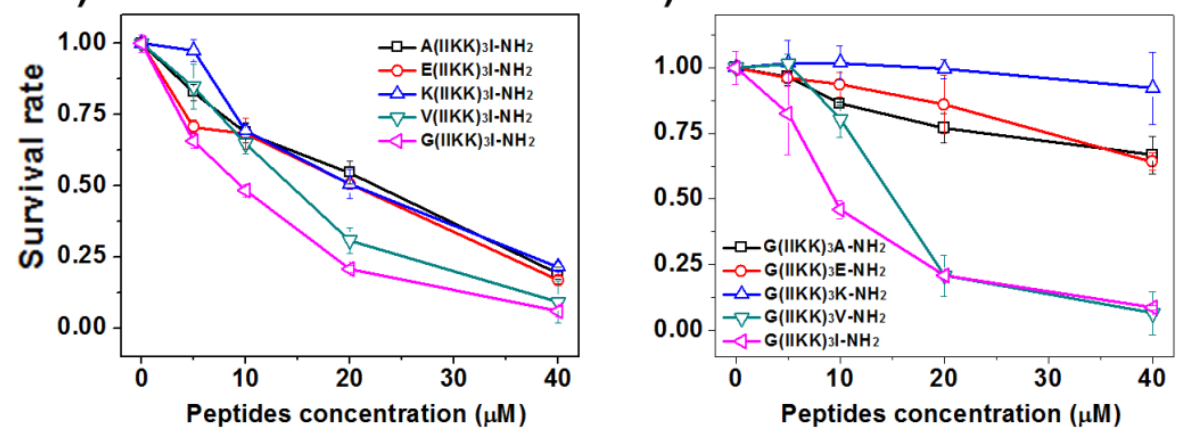

Figure 5. Bioactivities of the peptides against A,a) HpeG2, B,b) HeLa, C,c) HL60 and D,d) Jurkat cells measured by MTT assays. Briefly, peptides were added into the wells containing pre-incubated tumor cells and incubated for $24 \mathrm{~h}$, then $20 \mu \mathrm{L}$ of MTT was added into the wells and incubated for further $4 \mathrm{~h}$, the formazan was dissolved in DMSO and the absorbance at $570 \mathrm{~nm}$ was recorded. Cell 
survival rates were calculated relative to their controls.
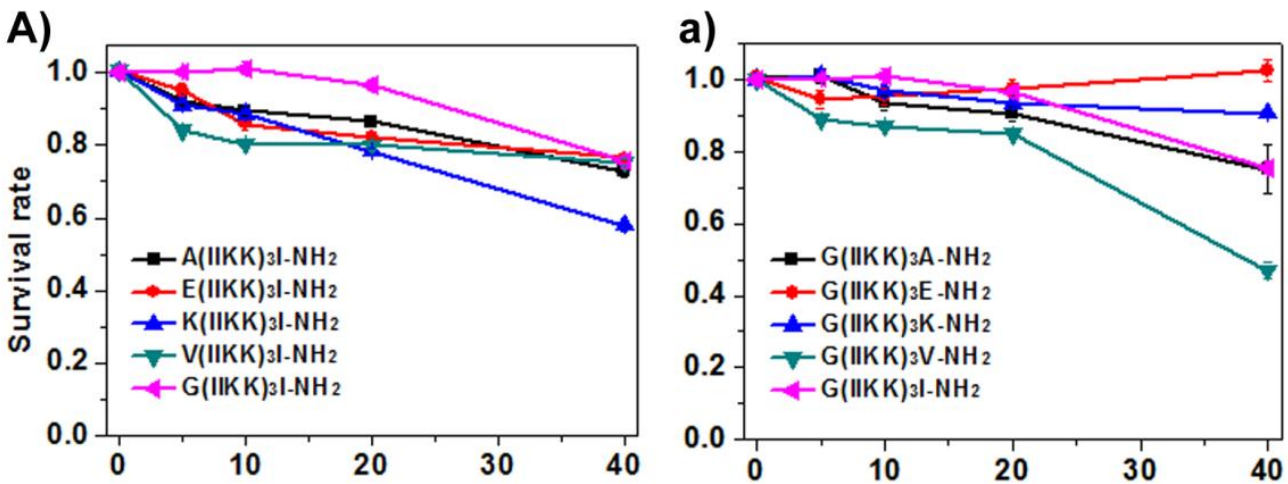

B)

b)
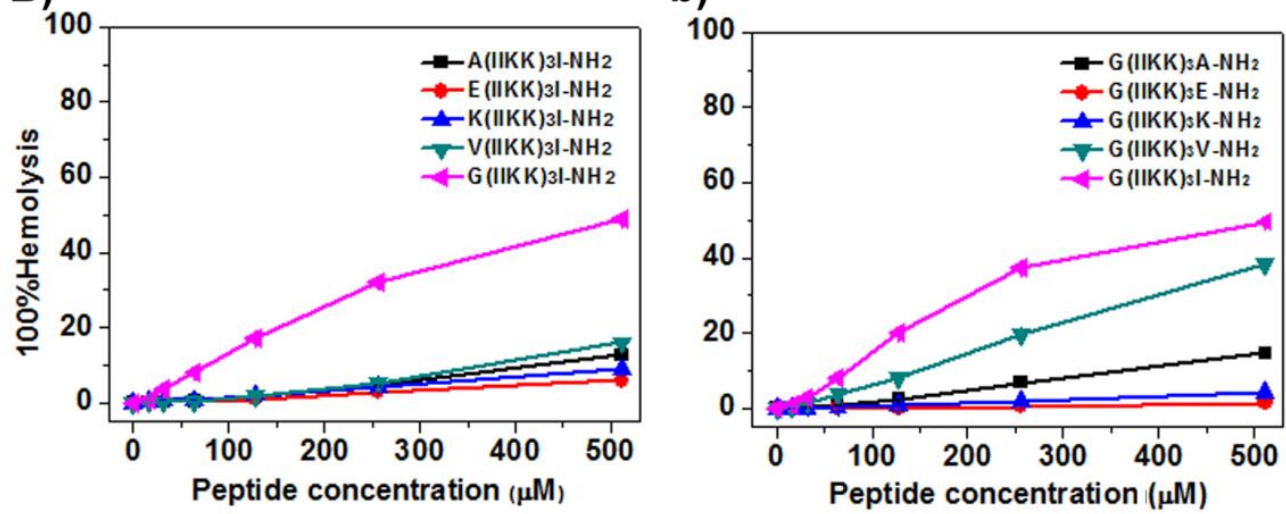

Figure 6. Cytotoxicity of each peptide toward A-a) human chondrocytes-articular (HCa) cells and B-b) human erythrocytes. Cytotoxicity against HCa cells was tested by MTT assays. Hemolytic activity of each peptide was tested by monitoring the hemoglobin release from human fresh blood cells after adding the peptide.

Figure 7 summarizes the relationship of the physical activities and bioactivities of the peptides studied. As shown in Figure 7A, high surface pressures always correlated well with high antitumor activities (Figure 7A, pink box). When the surface pressure dropped to and below $\sim 10 \mathrm{mN} / \mathrm{m}$, the peptides might become imbalanced in their amphiphilicity and their antitumor activities were thus decreased greatly (Figure 7A, blue box). Above 
$12 \mathrm{mN} / \mathrm{m}$, additional increase in surface pressure did not cause any favorable benefit to their antitumor activities (Figure 7A, pink box). Note that much higher surface pressures (e.g. more than $20 \mathrm{mN} / \mathrm{m}$ ) readily caused stronger hemolytic activities (Figure S2). As shown in Figure 7B, variation in hydrophobicity caused little impact on antitumor activity for the N-terminal variants (Figure 7B). However, the three C-terminal variants $\left(\mathrm{G}(\mathrm{IIKK})_{3} \mathrm{~A}-\mathrm{NH}_{2}, \mathrm{G}(\mathrm{IIKK})_{3} \mathrm{E}-\mathrm{NH}_{2}\right.$, and $\mathrm{G}(\mathrm{IIKK})_{3} \mathrm{~K}-\mathrm{NH}_{2}$, blue box, Figure 7B) had the similar degree of hydrophobicity (retention time: 17.1, 16.7, and $15.8 \mathrm{~min}$ ) to the three N-terminal variants $\left(\mathrm{E}(\mathrm{IIKK})_{3} \mathrm{I}-\mathrm{NH}_{2}: 17.5 \mathrm{~min}, \quad \mathrm{~V}(\mathrm{IIKK})_{3} \mathrm{I}-\mathrm{NH}_{2}: 16.9 \mathrm{~min}\right.$, and $\left.\mathrm{K}(\mathrm{IIKK})_{3} \mathrm{I}-\mathrm{NH}_{2}: 15.8 \mathrm{~min}\right)$ while their antitumor activities were greatly decreased. This can be ascribed to their lower surface pressures (Figure 7A). Although $\mathrm{G}(\mathrm{IIKK})_{3} \mathrm{~V}-\mathrm{NH}_{2}$ had a rather low helical content in negatively charged DPPG SUVs $\left(-[\theta]_{222 \mathrm{~nm}}=3.3 \times 10^{3}\right.$ deg. $\left.\mathrm{cm}^{2} \cdot \mathrm{dmol}^{-1}\right)$, it displayed comparable antitumor activities to $\mathrm{G}(\mathrm{IIKK})_{3} \mathrm{I}-\mathrm{NH}_{2}$ and the $\mathrm{N}$-terminal variants whose helicities were larger than $6.0 \times 10^{3} \mathrm{deg} \cdot \mathrm{cm}^{2} \cdot \mathrm{dmol}^{-1}$, as shown in Figure 7C. All these results suggest that surface physical activity rather than hydrophobicity or helicity governs the antitumor activities of both the N-terminal and C-terminal variants of $\mathrm{G}(\mathrm{IIKK})_{3} \mathrm{I}-\mathrm{NH}_{2}$. 

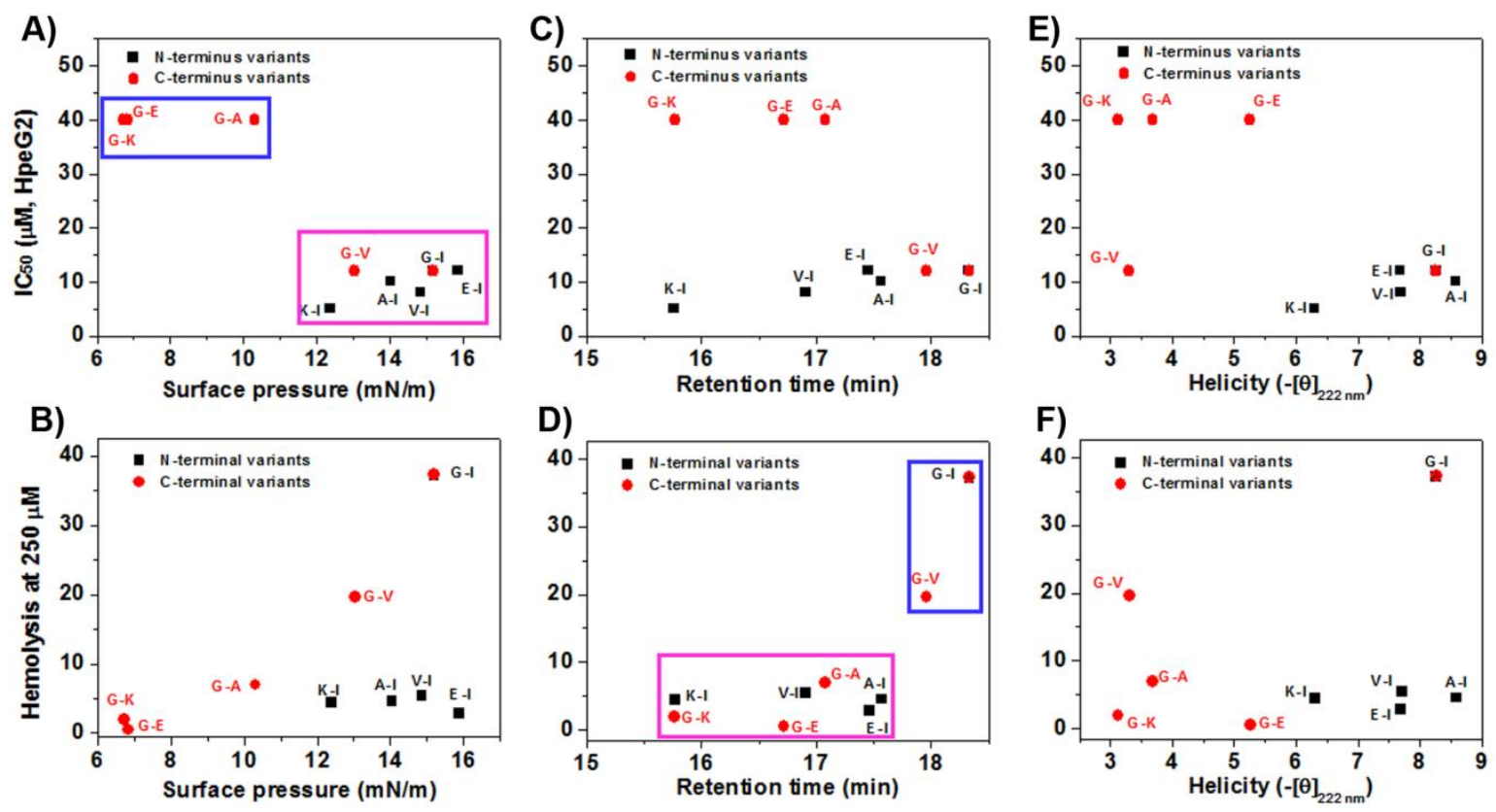

Figure 7. A,C,E) Relationship between antitumor activity $\left(\mathrm{IC}_{50}\right)$ and surface pressure, hydrophobicity (retention time), and helicity, respectively. Note that the $\mathrm{IC}_{50}$ values of more than $40 \mu \mathrm{M}$ were edited to $40 \mu \mathrm{M}$ for the three C-terminal variants $\left(\mathrm{G}(\mathrm{IIKK})_{3} \mathrm{~A}-\mathrm{NH}_{2}, \mathrm{G}(\mathrm{IIKK})_{3} \mathrm{E}-\mathrm{NH}_{2}\right.$, and $\left.\mathrm{G}(\mathrm{IIKK})_{3} \mathrm{~K}^{-\mathrm{NH}_{2}}\right)$. B,D,F) Relationship between hemolyticity and surface pressure, hydrophobicity (retention time), and helicity, respectively..

As shown in Figure 7D, it appeared that the hydrophobicity (retention time) of the peptides dictated their hemolytic activities. The peptides with retention times longer than 18 min showed obviously increased hemolytic activities, including $\mathrm{G}(\mathrm{IIKK})_{3} \mathrm{I}-\mathrm{NH}_{2}$ and $\mathrm{G}(\mathrm{IIKK})_{3} \mathrm{~V}-\mathrm{NH}_{2}$, although the latter had a rather low helical content in DPPG SUVs (Figure 7F). The $\mathrm{N}$-terminal variants including $\mathrm{A}(\mathrm{IIKK})_{3} \mathrm{I}-\mathrm{NH}_{2}, \mathrm{E}(\mathrm{IIKK})_{3} \mathrm{I}-\mathrm{NH}_{2}$, $\mathrm{V}(\mathrm{IIKK})_{3} \mathrm{I}-\mathrm{NH}_{2}$, and $\mathrm{K}(\mathrm{IIKK})_{3} \mathrm{I}-\mathrm{NH}_{2}$ showed lower hemolytic activities due to their low and moderate hydrophobicity (Figure 7D) and simultaneously, their higher surface pressures made them potent in antitumor activity (Figure 7A), indicating their enhanced 
cell selectivity relative to the control peptide $\mathrm{G}(\mathrm{IIKK})_{3} \mathrm{I}-\mathrm{NH}_{2}$. Although the other three C-terminal variants $\left(\mathrm{G}(\mathrm{IIKK})_{3} \mathrm{~A}-\mathrm{NH}_{2}, \mathrm{G}(\mathrm{IIKK})_{3} \mathrm{E}-\mathrm{NH}_{2}\right.$, and $\left.\mathrm{G}(\mathrm{IIKK})_{3} \mathrm{~K}-\mathrm{NH}_{2}\right)$ also showed lower hemolytic activities (Figure 7D), their antitumor activities were significantly decreased due to their lower surface pressures (Figure 7A), causing reduction in cell selectivity.

\section{Tumor Cell Membrane Disruption}

As $\mathrm{G}(\mathrm{IIKK})_{3} \mathrm{I}-\mathrm{NH}_{2}$ killed tumor cells by both disrupting tumor cell membranes and inducing tumor cell apoptosis (what has been done here about elucidating this mechanism in this work? It is not clear in this section here), ${ }^{22,}{ }^{23}$ we have performed the calcein release assay using $\mathrm{HpeG} 2$ and $\mathrm{HCa}$ cells to determine tumor/normal cell membrane permeability after peptide binding. Incubation with $20 \mu \mathrm{M} \mathrm{G}(\mathrm{IIKK})_{3} \mathrm{I}-\mathrm{NH}_{2}$ for $10 \mathrm{~min}$ resulted in about $60 \%$ calcein release from HpeG2 cells, indicating its rapid permeabilizing effect on cancer cell membranes (Figures 8A and 8a). As expected, increasing incubation time led to more membrane disruption and more than $80 \%$ calcein release was achieved after $2 \mathrm{~h}$ of incubation. The same trend was found for all the $\mathrm{N}$-terminal variants at the same concentration of $20 \mu \mathrm{M}$, which was slightly higher than their $\mathrm{IC}_{50}$ values $(\sim 10 \mu \mathrm{M})$. Consistent with the variation in their antitumor activities, there were significant differences in the membrane permeability of the C-terminal variants (Figure $8 \mathrm{a}) . \mathrm{G}(\mathrm{IIKK})_{3} \mathrm{~V}-\mathrm{NH}_{2}$ showed a similar cell membrane permeability to $\mathrm{G}(\mathrm{IIKK})_{3} \mathrm{I}-\mathrm{NH}_{2}$ (Figures 8a), well consistent with their similar antitumor activities 
(Figures 5a-5d). However, G(IIKK) ${ }_{3} \mathrm{~A}-\mathrm{NH}_{2}, \mathrm{G}(\mathrm{IIKK})_{3} \mathrm{E}-\mathrm{NH}_{2}$ and $\mathrm{G}(\mathrm{IIKK})_{3} \mathrm{~K}-\mathrm{NH}_{2}$ only caused about $25 \%$ calcein release even when incubated up to $2 \mathrm{~h}$, suggesting their lower membrane disruption ability, consistent with their low antitumor activities (Figures 5a-5d). These calcein release results suggest that membrane disruption constitutes the main mechanism of the antitumor behaviors of these peptides.

In contrast, all peptides induced significantly reduced calcein release from primary human $\mathrm{HCa}$ cell, consistent with their mildness to the cells. As shown in Figures 8B and $8 \mathrm{~b}, \mathrm{~K}(\mathrm{IIKK})_{3} \mathrm{I}-\mathrm{NH}_{2}, \mathrm{G}(\mathrm{IIKK})_{3} \mathrm{I}-\mathrm{NH}_{2}$, and $\mathrm{G}(\mathrm{IIKK})_{3} \mathrm{~V}-\mathrm{NH}_{2}$ induced about $10 \%$ calcein release, which was broadly in agreement with their relatively high toxicity to HCa cells in the series (Figures $6 \mathrm{~B}$ and $6 \mathrm{~b}$ ). Other peptides induced little calcein release after incubation for $2 \mathrm{~h}$ at a concentration of $20 \mu \mathrm{M}$, indicating that it is hard for them to disrupt HCa cell membranes. 

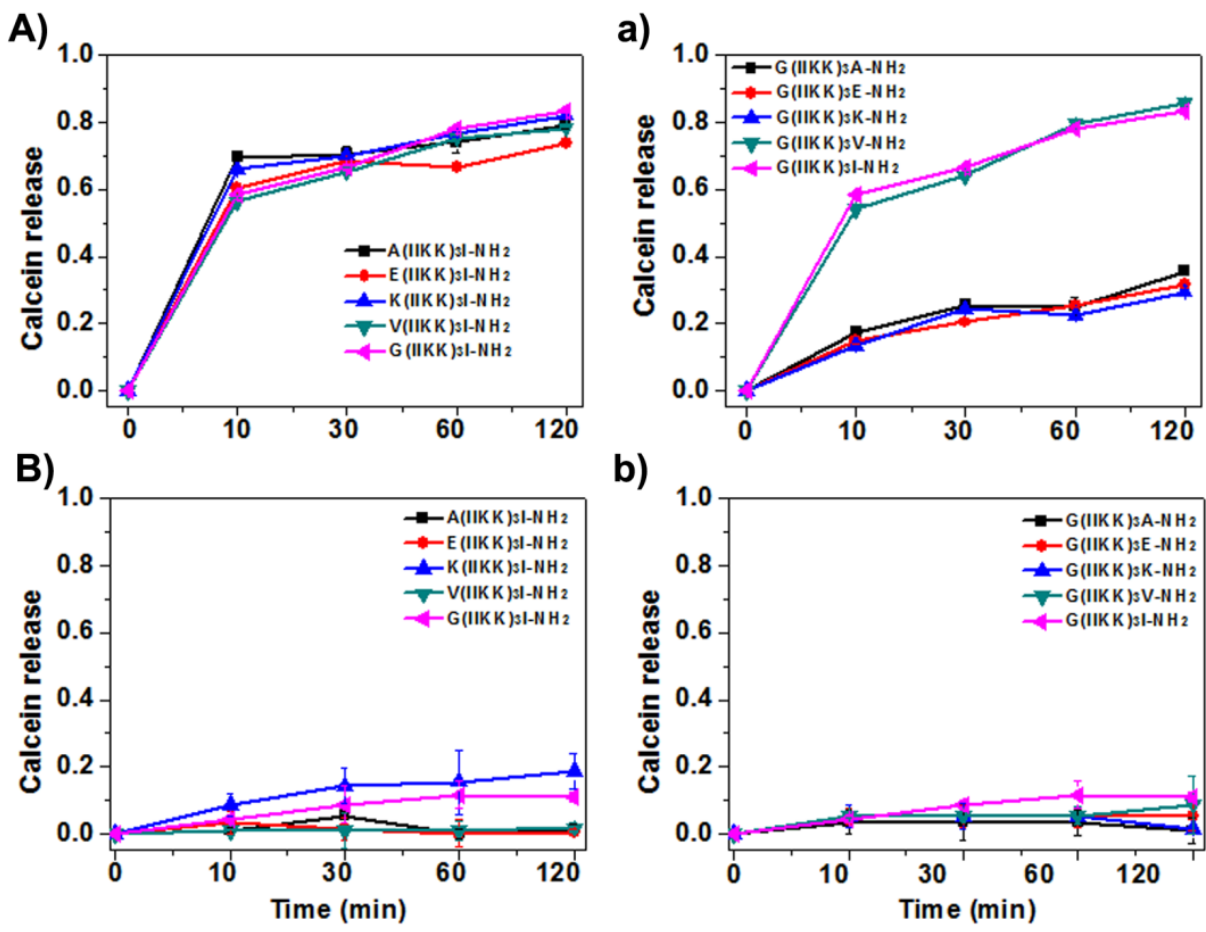

Figure 8. Calcein release from $\mathrm{HpeG} 2$ and $\mathrm{HCa}$ cells after treating with each peptide at a concentration of $20 \mu \mathrm{M}$ for 15, 30, 60 and 120 min, respectively. A,a) HpeG2 cells and B,b) HCa cells. The pre-incubated HpeG2/HCa cells were stained with calcein-AM $(1 \mu \mathrm{M})$ for 30 min in the dark and then each peptide was introduced into the wells at a concentration of $20 \mu \mathrm{M}$ and incubated for the indicated times. The fluorescence readings of the supernatants were tested and the calcein release rates were calculated compared to the control samples $(100 \%$ with 0.1 Triton X-100 and $0 \%$ only with PBS).

\section{CONCLUSIONS}

To better understand the effects of terminal amino acid modifications on the physical properties and bioactivity of the designed peptides and explore the basic relationship between them, we have designed two groups of peptides by replacing the N-terminal Gly or C-terminal Ile residue with Ala, Val, Glu and Lys residues from an well studied 
sequence $\mathrm{G}(\mathrm{IIKK})_{3} \mathrm{I}-\mathrm{NH}_{2}(\mathrm{G} 3)$. The N-terminal variants exhibited slight variations in their surface physical activity and helix-forming ability, relative to the control peptide G3. The surface pressures of G3 and its N-terminal variants were all kept between 12 and 16 $\mathrm{mN} / \mathrm{m}$ over which potent antitumor activities were observed. However, the decreased hydrophobicity of the N-terminal variants endowed them with much lower hemolytic activity than the control peptide G3, showing enhanced cell selectivity. On the contrary, the C-terminal variants showed marked variations in their surface activity and helix-forming ability upon terminal modifications. The lower surface pressures of $\mathrm{G}(\mathrm{IIKK})_{3} \mathrm{E}-\mathrm{NH}_{2}, \mathrm{G}(\mathrm{IIKK})_{3} \mathrm{~K}-\mathrm{NH}_{2}$, and $\mathrm{G}(\mathrm{IIKK})_{3} \mathrm{~A}-\mathrm{NH}_{2}$ led to their low antitumor activities, although they also showed very low hemolytic activity as a result of their decreased hydrophobicity. On the other hand, the C-terminal variant $\mathrm{G}(\mathrm{IIKK})_{3} \mathrm{~V}-\mathrm{NH}_{2}$ had a comparable surface pressure to G3 but stronger hydrophobicity than all other terminal variants in the series, displaying potent antitumor activities whilst remaining high hemolytic activity as well, in spite of its very low helical content. Unlike the N-terminal variants, the C-terminal variants thus did not exhibit clear increase in cell selectivity. This work has demonstrated that surface activity governs antitumor activity while hydrophobicity influences their toxicity to mammalian host cells. Terminal modifications provide a useful strategy to reduce the hemolytic activity of helical ACPs whilst retaining high antitumor activity.

\section{ASSOCIATED CONTENT}




\section{Supporting Information}

HPLC spectra of the peptide in the absence or presence of $10 \%$ FBS for $2 \mathrm{~h}$ or $40 \mathrm{~h}$. Helical wheel of $(\mathrm{IIKK})_{3} \mathrm{II}-\mathrm{NH}_{2}$, its surface pressure, hemolytic activity and antitumor activity against HpeG2 and HL60 cells. This material is available free of charge via the Internet at http://pubs.acs.org.

\section{AUTHOR INFORMATION}

\section{Corresponding Authors}

E-mail: xuh@upc.edu.cn (H.X); j.lu@ manchester.ac.uk (J.R.L.)

\section{Notes}

The authors declare no competing financial interest.

\section{ACKNOWLEDGEMENTS}

This work was supported by the National Natural Science Foundation of China under grant numbers 31271497 and 21373270, the Fundamental Research Funds for the Central Universities (12CX04052A and 14CX02189A). We thank UK Engineering and Physical Sciences Research Council (EPSRC) and Technology and Strategy Board (TSB) for support.

\section{REFERENCES}

(1) Gaspar, D.; Veiga, A. S.; Castanho, M. A. From Antimicrobial to Anticancer Peptides. A Review. Front. Microbiol. 2013, 4.

(2) Hoskin, D. W.; Ramamoorthy, A. Studies on Anticancer Activities of Antimicrobial Peptides. Biochim.

Biophys. Acta, Biomembr. 2008, 1778, 357-375. 
(3) Papo, N.; Shai, Y. Host Defense Peptides as New Weapons in Cancer Treatment. Cell. Mol. Life Sci.

CMLS 2005, 62, 784-790.

(4) Riedl, S.; Zweytick, D.; Lohner, K. Membrane-Active Host Defense Peptides-Challenges and Perspectives for the Development of Novel Anticancer Drugs. Chem. Phys. Lipids 2011, 164, 766-781.

(5) Yeaman, M. R.; Yount, N. Y. Mechanisms of Antimicrobial Peptide Action and Resistance. Pharmacol. Rev. 2003, 55, 27-55.

(6) Yeung, A. T. Y.; Gellatly, S. L.; Hancock, R. E. W. Multifunctional Cationic Host Defence Peptides and Their Clinical Applications. Cell. Mol. Life Sci. 2011, 68, 2161-2176.

(7) Zelezetsky, I.; Tossi, A. Alpha-Helical Antimicrobial Peptides-Using a Sequence Template to Guide Structure-Activity Relationship Studies. Biochim. Biophys. Acta, Biomembr. 2006, 1758, 1436-1449.

(8) Papo, N.; Shahar, M.; Eisenbach, L.; Shai, Y. A Novel Lytic Peptide Composed of DL-Amino Acids Selectively Kills Cancer Cells in Culture and in Mice. J. Biol. Chem. 2003, 278, 21018-21023.

(9) Papo, N.; Shai, Y. New Lytic Peptides Based on the D, L-Amphipathic Helix Motif Preferentially Kill Tumor Cells Compared to Normal Cells. Biochemistry 2003, 42, 9346-9354.

(10) Fadnes, B.; Uhlin-Hansen, L.; Lindin, I.; Rekdal, Ø. Small Lytic Peptides Escape the Inhibitory Effect of Heparan Sulfate on the Surface of Cancer Cells. BMC Cancer 2011, 11, 116.

(DOI: $10.1186 / 1471-2407-11-116)$

(11) Ren, S. X.; Shen, J.; Cheng, A. S.; Lu, L.; Chan, R. L.; Li, Z. J.; Wang, X. J.; Wong, C. C.; Zhang, L.; Ng, S. S. FK-16 Derived from the Anticancer Peptide LL-37 Induces Caspase-Independent Apoptosis and Autophagic Cell Death in Colon Cancer Cells. PLoS One 2013, 8, e63641.

(12) Matsuzaki, K. Control of Cell Selectivity of Antimicrobial Peptides Biochim. Biophys. Acta, 
Biomembr. 2009, 1788, 1687-1692.

(13) Kim, S.; Kim, S. S.; Lee, B. J. Correlation between the Activities of $\alpha$-Helical Antimicrobial Peptides and Hydrophobicities Represented as RP HPLC Retention Times. Peptides 2005, 26, 2050-2056.

(14) Huang, Y.; Wang, X.; Wang, H.; Liu, Y.; Chen, Y. Studies on Mechanism of Action of Anticancer Peptides by Modulation of Hydrophobicity within a Defined Structural Framework. Mol. Cancer Ther. 2011, $10,416-426$.

(15) Huang, Y.; He, L.; Jiang, H.; Chen, Y. Role of Helicity on the Anticancer Mechanism of Action of Cationic-Helical Peptides. Int. J. Mol. Sci. 2012, 13, 6849-6862.

(16) Wang, G. Post-Translational Modifications of Natural Antimicrobial Peptides and Strategies for Peptide Engineering Curr. Biotechnol. 2012, 1, 72-79.

(17) Dennison, S. R.; Harris, F.; Bhatt, T.; Singh, J.; Phoenix, D. A. The Effect of C-Terminal Amidation on the Efficacy and Selectivity of Antimicrobial and Anticancer Peptides Mol. Cell. Biochem. 2009, 332, 43-50.

(18) Crusca, E.; Rezende, A. A.; Marchetto, R.; Mendes-Giannini, M. J.; Fontes, W.; Castro, M. S.; Cilli, E. M. Influence of N-Terminus Modifications on the Biological Activity, Membrane Interaction, and Secondary Structure of the Antimicrobial Peptide Hylin-a1 Biopolyers (Pept. Sci.) 2011, 96, 41-48.

(19) Nguyen, L. T.; Chau, J. K.; Perry, N. A.; De Boer, L.; Zaat, S. A. J.; Vogel, H. J. Serum Stabilities of Short Tryptophan-and Arginine-Rich Antimicrobial Peptide Analogs PloS One 2010, 5, e12684.

(20) Pasupuleti, M.; Schmidtchen, A.; Chalupka, A.; Ringstad, L.; Malmsten, M. End-Tagging of Ultra-Short Antimicrobial Peptides by W/F Stretches to Facilitate Bacterial Killing PLoS One 2009, 4, e5285. 
(21) Schmidtchen, A.; Pasupuleti, M.; Mörgelin, M.; Davoudi, M.; Alenfall, J.; Chalupka, A.; Malmsten, M.

Boosting Antimicrobial Peptides by Hydrophobic Oligopeptide End Tags J. Biol. Chem. 2009, 284, 17584-17594.

(22) Hu, J.; Chen, C.; Zhang, S.; Zhao, X.; Xu, H.; Zhao, X.; Lu, J. R. Designed Antimicrobial and Antitumor Peptides with High Selectivity Biomacromolecules 2011, 12, 3839-3843.

(23) Chen, C.; Hu, J.; Zeng, P.; Pan, F.; Yaseen, M.; Xu, H.; Lu, J. R. Molecular Mechanisms of Anticancer Action and Cell Selectivity of Short $\alpha$-Helical Peptides Biomaterials 2014, 35, 1552-1561.

(24) Chen, C.; Chen, Y.; Yang, C.; Zeng, P.; Xu, H.; Pan, F.; Lu, J. R. High Selective Performance of Designed Antibacterial and Anticancer Peptide Amphiphiles ACS Appl. Mater. Interfaces 2015, 7 , 17346-17355.

(25) Richardson, J. S.; Richardson, D. C. Amino Acid Preferences for Specific Locations at the Ends of Alpha Helices. Science 1988, 240, 1648-1652.

(26) Chakrabartty, A.; Doig, A. J.; Baldwin, R. L. Helix Capping Propensities in Peptides Parallel Those in Proteins. Proc. Natl. Acad. Sci. U.S.A. 1993, 90, 11332-11336.

(27) Blondelle, S. E.; Ostresh, J. M.; Houghten, R. A.; Pérez-Payá, E. Induced Conformational States of Amphipathic Peptides in Aqueous/Lipid Environments. Biophys. J. 1995, 68, 351-359.

(28) Krause, E.; Beyerman, M.; Dathe, M.; Rothemund, S.; Bienert, M. Location of an Amphipathic $\alpha$-Helix in Peptides Using Revoersed-Phase HPLC Retention Behavor of D-Amino Acid Analogs. Anal. Chem. 1995, 67, 252-258. Chen, Y.; Guarnieri, M. T.; Vasil, A. I.; Vasil, M. L.; Mant, C. T.; Hodges, R. S. Role of Peptide Hydrophobicity in the Mechanism of Action of $\alpha$-Helical Antimicrobial Peptides. Antimicrob. Agents 
Chemother. 2007, 51, 1398-1406.

(30) Kyte, J.; Doolittle, R. F. A Simple Method for Displaying the Hydropathic Character of a Protein $J$. Mol. Biol. 1982, 157, 105-132.

(31) Mant, C. T.; Kovacs, J. M.; Kim, H. -M.; Pollock, D. D.; Hodges, R. S. Intrinsic Amino Acid Side-Chain Hydrophilicity/Hydrophobicity Coefficients Determined by Reversed-Phase High-Performance Liqud Chromatography of Model ppetides: Comparison with Other Hydrophilicity/Hydrophobicity Scales. Biopolymers (Pept. Sci.) 2009, 92, 573-595.

(32) Spicer, V.; Lao, Y. W.; Shamshurin, D.; Ezzati, P.; Wilkins, J. A.; Krokhin, O. V. N-Capping Motifs Promote Interaction of Amphipathic Helical Peptides with Hydrophobic Surfaces and Drastically Alter Hydrophobicity Values of Individual Amino Acids. Anal. Chem. 2014, 86, 11498-11502. Brockman, H. Lipid Monolayers: Why Use Half a Membrane to Characterize Protein-Membrane Interactions? Curr. Opin. Struct. Biol. 1999, 9, 438-443.

(34) Eiríksdóttir, E.; Konate, K.; Langel, Ü.; Divita, G.; Deshayes, S. Secondary Structure of Cell-Penetrating Peptides Controls Membrane Interaction and Insertion. Biochim. Biophys. Acta, Biomembr. 2010, $1798,1119-1128$.

(35) Deshayes, S.; Plénat, T.; Aldrian-Herrada, G.; Divita, G.; Le Grimellec, C.; Heitz, F. Primary Amphipathic Cell-Penetrating Peptides: Structural Requirements and Interactions with Model Membranes Biochemistry 2004, 43, 7698-7706.

(36) Deshayes, S.; Heitz, A.; Morris, M. C.; Charnet, P.; Divita, G.; Heitz, F. Insight into the Mechanism of Internalization of the Cell-Penetrating Carrier Peptide Pep-1 through Conformational Analysis. Biochemistry 2004, 43, 1449-1457. 
(37) Blondelle, S. E.; Houghten, R. A. Design of Model Amphipathic Peptides Having Potent Antimicrobial Activities Biochemistry 1992, 31, 12688-12694.

(38) Tossi, A.; Sandri, L.; Giangaspero, A. Amphipathic, $\alpha$-Helical Antimicrobial Peptides Biopolymers (Pept. Sci.) 2000, 55, 4-30. 


\section{Table of Content:}

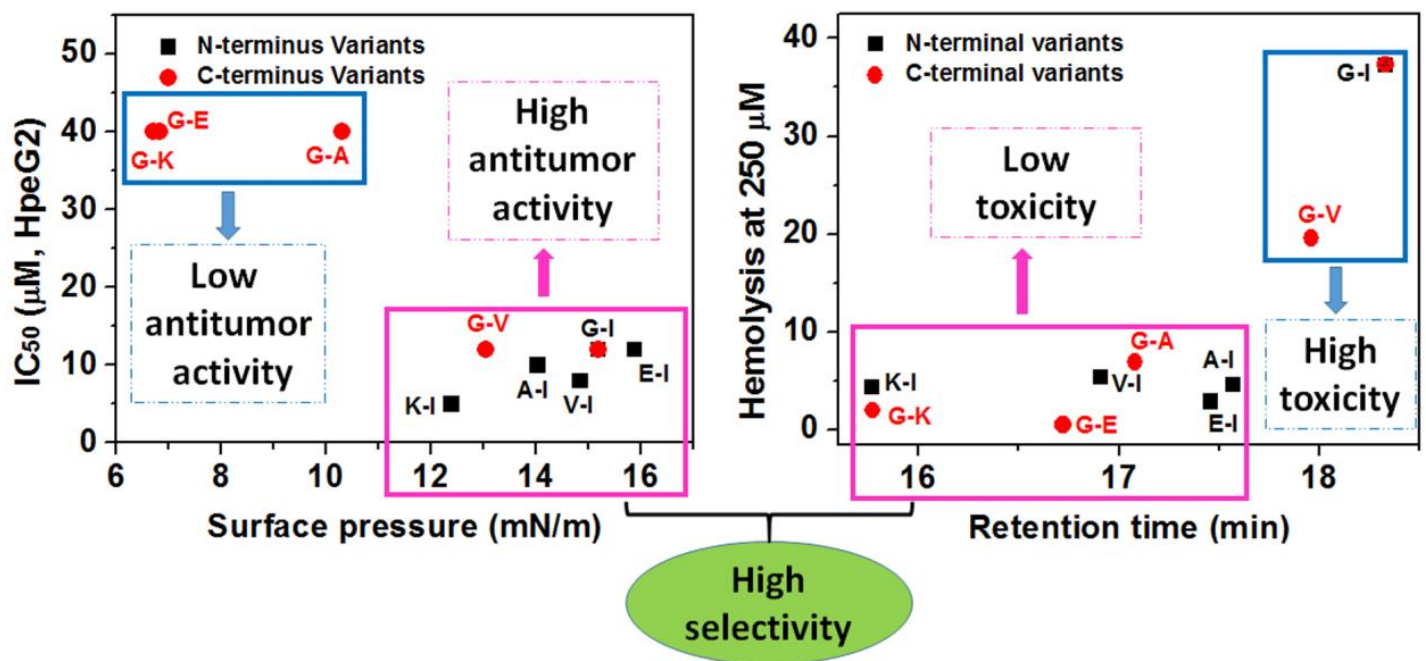

